\title{
Research progress on resource utilization of leather solid waste
}

\author{
Yanchun Li, Ruijun Guo, Wenhui Lu and Deyi Zhu
}

\begin{abstract}
Leather making is the process of converting raw hides into leather. Amounts of solid waste containing hazardous and high value components are generated during this process. Therefore, the elimination of the potential pollution and resource utilization of leather solid waste are the primary research hotspots. Herein, we comprehensively review the recent advances in the resource utilization of leather solid waste generated from chrome tanning including the utilization of tannery hair waste, untanned solid waste, chrome-containing leather solid waste, tannery sludge and finished leather waste, emphasizing on the general and novel utilization approaches. Finally, the remaining challenges and perspectives were summarized, in order to accelerate the development of resource utilization of leather solid waste.
\end{abstract}

Keywords: Leather solid waste, Tannery hair waste, Untanned solid waste, Chrome-containing leather solid waste, Tannery sludge, Finished leather waste

\section{Introduction}

As a traditional and ancient industry, leather making not only meets the demand of social development, but also contributes to the global economy [1]. As reported, processing one ton of wet salted hides/skins can produce about $200 \mathrm{~kg}$ finished leather together with about $350 \mathrm{~kg}$ non-tanned solid waste, about $250 \mathrm{~kg}$ tanned solid waste, about $200 \mathrm{~kg}$ waste lost in wastewater [2]. In the global leather processing, about 6 million tons of solid wastes were generated annually [3], while China and India as main leather manufacturing countries individually generated 1.4 million tons/year [4] and 150,000 tons/year [5]. However, amounts of acids, alkalis, salts, heavy metal ions and collagen were contained in those leather solid wastes, which will threaten environment and human health or cause the waste of available resource. Therefore, developing feasible methods for avoiding, eliminating the pollutant and resource utilization of leather solid wastes urgently needed.

Based on the different procedure of leather processing, leather solid waste generated from chrome tanning are generally classified as tannery hair waste, untanned solid waste, chrome-containing leather solid waste, tannery

*Correspondence: qlulyc@126.com

School of Light Industry and Engineering, Qilu University of Technology (Shandong Academy of Sciences), Jinan 250353, China sludge and finished leather waste. Numerous researches of the treatment or utilization of these solid wastes have been reported and some have been reviewed, such as, Rouse et al. summarized keratin-based biomaterials for biomedical applications [6]. Shavandi et al. introduced the dissolution, extraction and biomedical application of keratin [7]. Sundar et al. reviewed various recovery and utilization methods of chromium-tanned proteinous wastes from leather making [8]. Jiang et al. discussed the major achievements in the treatment of leather solid waste, concerning on the treatment of chromium-tanned solid wastes [9].

In this review, we focused on the development of resource utilization of leather solid wastes generated from chrome tanning, emphasizing on studies published in the most recent years of 2009 2019. The methods of extraction and application of keratin obtained from tannery hair waste were briefly introduced, focusing on the novel extraction methods and application of keratin in biomedical, leather making and adsorption materials. For the untanned solid waste, the utilization of trimming and fleshing of raw hide and liming skin were introduced individually, such as, the production and applications of industrial gelatin, the extraction of oil, the preparation of biofuel and leather fatliquor. Versatile applications of chrome-containing leather solid waste were 
comprehensively reviewed, containing the direct usage without dechroming of adsorption materials, conductive materials, electrostatic flocking and regenerated fiber leather, reusage after dechromisation treatment in leather and paper making. Newly reported reusing methods of tannery sludge were surveyed involving compost, anaerobic digestion, preparation of building materials, oil and adsorbent. The potentially reused methods of finished leather waste in producing regenerated leather composites and blended fabrics were mainly presented. Finally, the remaining challenges and future perspectives were also proposed.

\section{Resource utilization of tannery hair waste}

For the traditional hair-destruction unhairing technology, amount of wastewater with high value of COD, BOD, TDS and sulfide are produced because of the dissolve of hair [10]. To efficiently treat organic matter in the wastewater, expensive biotechnology was used and large number of sludges were also produced. Subsequently, newly hair-saving unhairing technology have been developed and applied in industry, which can recover $95 \%$ of the hair and reduce pollutant producing in the wastewater. Currently, the recovered tannery hair waste has captured extensive attention of researchers, focusing on the study of extraction and application of keratin.

\subsection{Extraction of keratin}

Keratin is a group of insoluble and fibrous proteins produced in certain epithelial cells of vertebrates, such as hair, wool, feathers, nails, horns, whale baleen and turtle scutes [11]. Compared with other fibrous proteins, keratin has high sulfur content, high structural and strong resistance to chemical attacks [12]. Based on that, it is a challenge to dissolve, extract and apply of keratin.

Until now, for the extraction of keratin from tannery hair waste, many chemical and physiochemical methods have been developed by destroying chemical bonds of disulfide bonds, hydrogen bonds and ionic bonds in keratin, such as, mechanical extraction, reduction [13], oxidation [14], acid hydrolysis [15-17], alkali hydrolysis [18], enzymatic hydrolysis [19], alkali-enzymatic hydrolysis [20, 21], microwave irradiation [22] and ionic liquid extraction [23, 24]. The advantages and disadvantages of these extraction methods were listed in Table 1 . The solubilized keratin can be obtained using mechanical extraction method by heating and pressurizing, which requires large scale apparatus with high energy consumption. Reduction method extracts keratin by using reducing agents, such as mercaptoethanol, in order to break disulfide bonds (-S-S-). Although keratin with high yield and large molecular weight were obtained, thiol containing chemicals are expensive, toxic and harmful to human health and environment. Oxidation method uses oxidizing reagents such as formic or peracetic acid to extract keratin by oxidizing disulfide bonds of keratin to sulfonic acid $\left(-\mathrm{SO}_{3} \mathrm{H}\right)$. The operation process is simple but time consuming, which needs more than $24 \mathrm{~h}$ to obtain reasonable keratin yield. The acid or alkali hydrolysis method should rigidly control the keratin hydrolysis degree and large amounts of alkaline and acids are required which might cause secondary pollution. Enzymatic hydrolysis is proposed to extract keratin by using suitable enzymes under mild reaction condition, but it still requires high cost and long reaction time. The homogeneous heat distribution and internal heat generation of microwave irradiation can reduce extraction time, but relatively low extraction yield is achieved. Ionic liquid extraction uses ionic liquid with low vapour pressure, high ion conductivity, high thermal stability and nonvolatility to extract keratin, but a part of water soluble amino acids can be lost and the extraction procedure needs to be performed at inert atmosphere requiring expensive specialized equipment.

Table 1 The advantages, disadvantages and applications of the extraction methods for keratin

\begin{tabular}{|c|c|c|c|}
\hline Method & Advantage & Disadvantage & Application \\
\hline $\begin{array}{l}\text { Mechanical } \\
\text { extraction }\end{array}$ & $\begin{array}{l}\text { Simple process, low cost, high } \\
\text { efficiency }\end{array}$ & $\begin{array}{l}\text { High equipment requirements, high energy } \\
\text { consumption, not easy to control }\end{array}$ & Animal feed \\
\hline Reduction & $\begin{array}{l}\text { Mild conditions, high keratin yield, } \\
\text { large molecular weight }\end{array}$ & $\begin{array}{l}\text { Complicated operation process, unstable } \\
\text { keratin solution }\end{array}$ & Spinning; adsorbent \\
\hline Oxidation & Simple process, low pollution & Low molecular weight & Animal feed \\
\hline $\begin{array}{l}\text { Acid/alkali } \\
\text { hydrolysis }\end{array}$ & $\begin{array}{l}\text { Simple process, small damage to } \\
\text { cystine }\end{array}$ & $\begin{array}{l}\text { Causing amino acid loss, corrosion equipment, } \\
\text { secondary pollution, not easy to control }\end{array}$ & Animal feed, leather auxiliaries \\
\hline $\begin{array}{l}\text { Enzymatic } \\
\text { hydrolysis }\end{array}$ & $\begin{array}{l}\text { Mild conditions, environmentally } \\
\text { friendly }\end{array}$ & High cost & $\begin{array}{l}\text { Food packaging film, cosmetics, } \\
\text { biomedical materials }\end{array}$ \\
\hline $\begin{array}{l}\text { Microwave } \\
\text { irradiation }\end{array}$ & $\begin{array}{l}\text { Short operation time, environmentally } \\
\text { friendly, small side reaction }\end{array}$ & Low molecular weight & Biomedical materials, fertilizers \\
\hline $\begin{array}{l}\text { Ionic liquid } \\
\text { extraction }\end{array}$ & $\begin{array}{l}\text { High solubility, environmentally } \\
\text { friendly }\end{array}$ & Potentially toxic, high cost & $\begin{array}{l}\text { Protein fiber blended membrane, } \\
\text { regenerated keratin fiber }\end{array}$ \\
\hline
\end{tabular}


For instance, Rajabinejad et al. [25] extracted keratin from wool fibers with different extraction methods, such as, oxidation, reduction, sulfitolysis and superheated water hydrolysis, and the physicochemical properties of these keratin were compared. Although similar extraction yields were obtained, the characterization results showed that the time, cost and environmental sustainability of these methods were different. Considering the similar molecular weights, sulfitolysis using sodium metabisulfite as extraction reagents seemed to be the cheapest and least harmful extraction method, comparison with oxidative and reductive extraction using peracetic acid and dithiothreitol as reagents respectively. And low molecular weight of the peptides was obtained by superheated water hydrolysis, which is easy to accomplish on a large scale and a relative cheap and environmentally friendly method [25].

To validly avoid the potential secondary pollution during keratin extraction procedure, simple, highly efficient and environmentally friendly methods using low or no toxic reagents were urgently needed. Recently, some kinds of innovation methods have been developed, such as, ionic liquid extraction and deep eutectic solvent extraction method. Ionic liquid (IL) as green solvent has been used to solubilize wool and extract keratin, Ghosh et al. [26] chosen 1-butyl-3-methylimidazolium chloride $\left([\mathrm{BMIM}]^{+} \mathrm{Cl}^{-}\right)$to dissolve raw wool samples and investigated the effect of temperature at 120,150 and $180{ }^{\circ} \mathrm{C}$ on the thermomechanical, morphological and protein profiles of regenerated keratin-based materials. With the increasing of IL temperature, amounts of water soluble peptides and amino acids were generated. But after precipitation with water, the yields of regenerated solid wool protein drastically reduced from $57 \mathrm{wt} \%$ to $18 \mathrm{wt} \% \mathrm{com}-$ pared to the raw wool (over 90\%). The average cysteine content was also decreased from $8.91 \mathrm{~mol} \%$ to 0.99 mol\% by analyzing the amino acid composition. The average breaking stress decreased and the percentage of strain increased rapidly. Otherwise, the regenerated keratin obtained at $180^{\circ} \mathrm{C}$ showed dense fibrous network morphology and more excellent thermal processing properties. These results illustrated that cysteine acted as an important role in creating disulphide cross-linking among keratin chains [26]. Similar to IL, deep eutectic solvent (DES) is a class of the complexation of hydrogen bond acceptors (HBA) and hydrogen bond donors (HBD) with low freezing point, which has also been applied to extraction keratin from hairs and leathers. Wang et al. [12] used the mixture of choline chloride and oxalic acid at a molar ratio of 1:2 as DES for extraction keratin from rabbit hair, followed by dialysis, filtration and freeze-drying. The deconstruction of $\alpha$-helix structure of rabbit hair and the broken of disulfide bond linkages occured during the dissolution and extraction procedure. The results indicated that the dissolution of rabbit hair significantly enhanced with the increasing of temperature and reached $88 \%$ at $120^{\circ} \mathrm{C}$. The keratin displayed flaky powders after freeze-drying, which had a molecular weight in the range of $3.8 \sim 5.8 \mathrm{kDa}$ with high proportion (59.8 wt\%) of serine, glutamic acid, cysteine, leucine and arginine [12]. However, for these mentioned reagents, the extraction procedure needed to precisely control the solution temperature and the waste hair also needed to be cut into small pieces.

In order to find low or no toxic extraction reagents, Wang et al. [24] applied L-cysteine as reducing agent displaced the commonly used venenous 2-mercaptoethanol to extract keratin from wool by cleaving the disulfide bonds. The dissolubility of wool treated with sulfites, thiols, enzymes, ionic liquids and L-cysteine was investigated, and the results showed that better dissolubility (72\%) can be achieved by dissolving wool in L-cysteine at $75^{\circ} \mathrm{C}$ for $5 \mathrm{~h}$. Besides, X-ray diffraction (XRD), Fourier transform infrared spectroscopy with attenuated total reflection technology (ATR-FTIR), solid state nuclear magnetic resonance $\left({ }^{13} \mathrm{C} N M R\right)$ and Raman spectra were used to characterize the structures and properties of the regenerated keratin from L-cysteine, which indicated that the content of $\alpha$-helix structures and S-S crosslinkages for the regenerated keratin decreased compared with the natural wool [27].

To establish novel eco-friendly method, Cassoni et al. [28] proposed a detergent treatment with membrane purification method to efficiently extract keratin from pig hair, using a commercial detergent named Mistolin ${ }^{\circ}$ HTG 50. The obtained solution with high protein content and purity can be achieved both at laboratory scale and pilot scale-up. Compared with other studies, this developed method was significantly simple, eco-friendly without using harmful reagents and time-saving [28].

\subsection{Application of keratin}

As mentioned, different extraction methods produced different molecular weight of keratin from tannery hair waste, which has been applied in diverse fields. As an important protein resource, the extracted keratin were mainly applied as biomedical material, adsorbent and leather auxiliaries (Table 1).

\subsubsection{Application in biomedicine}

For the biomaterials research, one of the hot spots is developing kinds of matrix or scaffolding system to mimic the structure and function of native tissue [6]. Due to the intrinsic biocompatibility, mechanical durability, biodegradability and natural abundance, the extracted keratin from tannery hair waste has been used to fabricate into versatile biomaterial forms 
including films, hydrogels, sponges, scaffolds and composites, which has been applied in biomedical field, such as, implantable biomedical materials [29, $30]$, nerve defect repair materials [31, 32], wound repair materials [33, 34], blood contact materials [35] and drug sustained release materials [36, 37].

For applications in tissue engineering and wound healing, the properties of biocompatibility and absorptivity are the basis of designing scaffold for cell culture. Sponge and hydrogel forms of keratin-based materials attracted much attentions. For the traditional synthesis procedure of keratin-based sponge and hydrogel, complicated preparation steps needed. Firstly, keratin should be extracted from waste hair, then modified functional groups or grafted copolymer on the surface of keratin, followed by concentration, dialysis and lyophilization [38-40]. To simplify the synthesis procedure, Ozaki et al. [41] proposed a simple method to prepare a sponge-like porous hydrogel of wool keratin using the extraction solution containing guanidine hydrochloride and 2-mercaptoethanol followed by dialysis for both aggregation of keratin and recrosslink. The apparatus for preparing keratin hydrogel by dialysis was shown in Fig. 1. After freeze-drying, the gel showed highly porous structure and fast-swelling property in rehydration. During the tensile test and the measurement of dynamic viscoelasticity, high mechanical strength was also achieved. Three different types of animal cells, namely

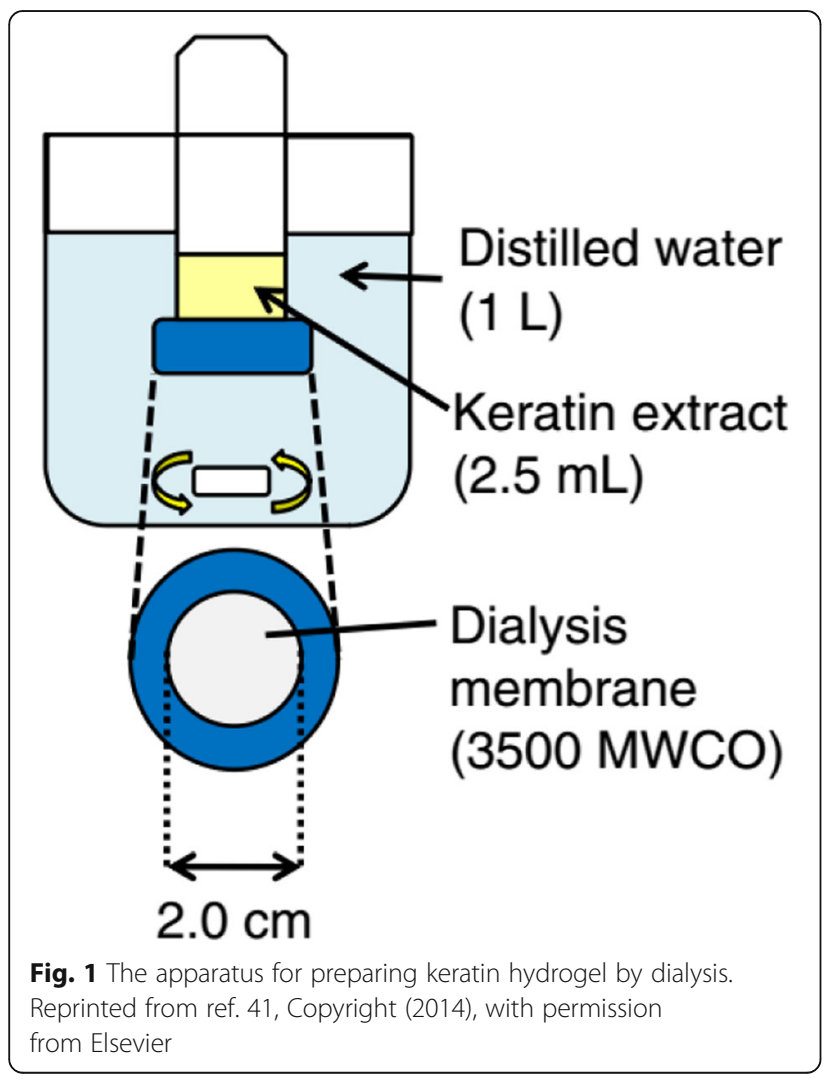

PC12 cells, HOS cells and murine embryonic fibroblasts, well proliferated and grew on the surface of it, meaning that the prepared keratin hydrogel was also available as a scaffold for cell culture [41]. Besides, novel materials with excellent antibacterial functionality and new antibacterial strategies were also required. Aluigi et al. [42] prepared photoactive methylene blue doped wool keratin films by solvent casting. Antimicrobial photodynamic therapy (APDT) was used to kill bacteria upon irradiation with visible light. The results showed that the swelling ratio and the $\mathrm{MB}$ release increases with the increasing of $\mathrm{pH}$ value. By fine-tuning the irradiation time and the concentration of $\mathrm{MB}$ in the films, the generation of reactive oxygen species (ROS) and singlet oxygen was readily triggered and controlled. Although sulfonated amino acids occurred slightly photo-oxidation, no significant photodegradation on keratin was induced by the ROS attack. Moreover, films doped with high MB concentration showed almost completely killing S. aureus (99.9\%) and proportional increasing of the killing effect was accomplished by increasing irradiation time [42].

For the application in drug delivery or release, minimizing the solvent usage for the fabrication of the drug carrier is the keypoint of research on biomaterial. Tran's group prepared a series of cellulose (CEL) and/or chitosan (CS)keratin (KER) composites (CEL/CS + KER) by using ionic liquid as solvent, which can potentially apply in biomedical field [43-45]. In order to simplify the preparation procedure and enhance the mechanical property and biocompatibility of these keratin-based composites, butylmethylimmidazolium chloride $\left([\mathrm{BMIM}]^{+} \mathrm{Cl}^{-}\right)$was used as the sole solvent to dissolve KER, CEL, CS and synthesize the composites in a single step. Otherwise, to study these composites in drug release application, ciprofloxacin (CPX) doped one or two or three of CEL, CS and KER composites were synthesized [43]. The releasing rates for CPX by these as-prepared composites have been evaluated, showing that CEL, CS or [CEL + CS] composites are faster than KER composites and the CPX release rate can be controlled and tuned by adjusting the KER concentration in the composites. Moreover, the [CEL + CS + KER] composites have combined properties of its three components with high mechanical strength, hemostasis and bactericide and controlled drug release [43]. Besides, in order to reduce the cardiotoxicity of doxorubicin for heart, Aluigi et al. [46] prepared doxorubicin/keratin nanoparticles (DOX-KNPs) by encapsulating this anticancer drug into keratin nanoparticles through ionic gelation and aggregation, with simple preparation and purification procedures and using nontoxic solvents. The performance of these two prepared DOX-KNPs were evaluated thor-

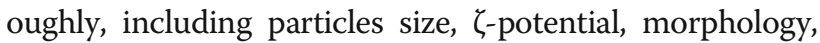
chemical interaction between keratin and doxorubicin. The results showed that both DOX-KNPs have tunable 
hydrodynamic diameters, high yields and encapsulation efficiency (>70\%). Doxorubicin release profiles under different $\mathrm{pH}$ conditions have also been investigated to assess the behaviour of these two DOX-KNPs in physiological $(\mathrm{pH}$ 7.4) and slight acidic tumour microenvironment $(\mathrm{pH}$ 4.5), demonstrating that doxorubicin was released more slowly from DOX-KNPs prepared using ionic gelation (DOX-KNPs-IG) in pH 7.4 and more rapidly and for longterm period in acidic condition, compared with aggregation prepared DOX-KNPs (DOX-KNPs-Agg). Moreover, preliminary in vitro cytotoxicity studies illustrated that DOX-KNPs-IG is more efficient for cell killing of MDAMB-231 and MCF-7 breast cancer cells than DOX-KNPsAgg, which provided an alternative appoach for cancer therapy [46].

\subsubsection{Application in adsorbent}

Owing to the numerous polar and ionizable groups, keratin from tannery hair waste have been applied as promising biosorbents to adsorb/remove metal ions and organic compounds, such as, dye [47], $\mathrm{Cu}$ (II) [48], Co (II) [49], $\mathrm{Ni}$ (II), $\mathrm{Pb}$ (II) [50] and $\mathrm{Cr}$ (VI) [51].

The ideal adsorbents for pollutant removal should have high specific surface area, high porosity, high adsorption capacity, numerous functional groups, less or non-toxicity and low cost. Electrospun nanofibre produced by electrospinning with excellent porosity, surface area and permeability have been applied as adsorbents individually or combined with other biomaterials. Aluigi et al. [51] prepared electrospinning hydrolyzed keratin/ polyamide 6 (HK/PA6) blends nanofibre mats in formic acid to efficiently adsorb Cr (VI), using alkaline hydrolysis method to extract keratin from wool and electrospinning technology. Intermolecular interactions and good compatibility between HK and PA6 were shown by the viscosity measurements results. The as-prepared nanofibre mats were used to adsorb $\mathrm{Cr}$ (VI) in the optimum acidic $\mathrm{pH}$ condition with maximum adsorption capacity of $55.9 \mathrm{mg} / \mathrm{g}$. The adsorption mechanism was simulated by kinds of kinetics and thermodynamic models, showing that ion-exchange occurred between $\mathrm{Cr}(\mathrm{VI})$ and HK/PA6 nanofibres [51]. Except the fiber form, keratin sponges also exhibited high porosity and specific surface area, although the mechanical property was weak. To solve the drawback, Song et al. [52] incorporated cellulose nanocrystal $(\mathrm{CNC})$ as reinforcing building blocks in keratin sponge to prepare three-dimensional bioadsorbent, which were applied to remove dyes from aqueous solution. The adsorption results showed that the adsorption capacities of the synthesized CNC-reinforced keratin sponges for Reactive Black 5 and Direct Red 80 were 1201 and $1070 \mathrm{mg} / \mathrm{g}$, respectively. Moreover, the bioadsorbent can reuse five times for adsorption these two dyes and the removal efficiencies remain above $80 \%$ [52].
Li's group prepared keratin sponges using keratin extracted from abandoned bovine hair to efficiently remove dyes in wastewater, which have excellent adsorption performance. Especially for the nano-magnetic keratin sponge, the separation of adsorbents and analytes was rapidly by the external magnetic field and good adsorption efficiency was also achieved after reuse for 15 times [53, 54].

\subsubsection{Application in leather making process}

The other significant application of keratin extracted from tannery hair waste is to be reused in leather making process. Since 1960s, many scholars have studied keratin as retanning agent and finishing agent, and discarded feather proteins were originally used as retanning fillers for industrial production $[55,56]$. The next decades, domestic researchers produced leather brightener using hairy casein from pig hair. And numerous studies have been confirmed that hydrolyzed keratin as retanning filler can effectively improve the fullness, elasticity and dyeing performance of the leather. For instance, Liang et al. [57] used dicyandiamide as functional monomer and formaldehyde as cross-linking agent to prepare keratin filler applied in tanning filling process. The finished leather showed flat grain surface, obvious thickening effect, good physical and mechanical properties [57]. Except extraction keratin from tannery hair waste, Shi's group [58] extracted polypeptides from bovine waste hair to prepare protein filling agent (HPFA) and investigated its inhibitory activity on the oxidation of $\mathrm{Cr}$ (III). For the preparation of HPFA, bovine hair was firstly hydrolyzed in $\mathrm{NaOH}$ solution, then centrifuged to collect supernatant which was subsequently adjusted $\mathrm{pH}$ with $\mathrm{HCl}$ and reacted with glycerol triglycidyl ether. To study the reduction performance of HPFA, several parameters were investigated, such as temperature, reaction time and HPFA dosage. The results showed that the obtained HPFA exhibited remarkable reducing ability to transfer $\mathrm{Cr}$ (VI) to $\mathrm{Cr}$ (III) in solution $\mathrm{pH}$ lower than 6.0. Moreover, compared with commercial protein filling agent made from collagen hydrolysate, HPFA also exhibited higher activity to inhibit $\mathrm{Cr}$ (III) oxidation both in chrome liquor and in leather, attributed to the abundant sulfhydryl groups in HPFA [58].

\section{Resource utilization of untanned solid waste}

The untanned solid waste mainly include waste from trimming of raw hide and liming skin and fleshing, containing large amount of collagen and grease. To sufficient usage of these protein-rich wastes, various kinds of methods and technologies have been proposed, focusing on the preparation of collagen/gelatin by using acid, alkali and enzyme hydrolysis methods and their subsequent applications. Moreover, grease waste residue can 
also be used to extract oils and fats, which can be applied as biofuel and leather fatliquor.

\subsection{Preparation of collagen/gelatin}

Nowadays, mature technologies have been developed and widely used to prepare collagen or gelatin from waste skin scraps, including acid, alkali and enzymatic hydrolysis. Amongst them, alkali hydrolysis has been proved to be feasible in industrial production, and typical preparation procedures of industrial gelatin were shown in Fig. 2. Besides, studies have also been reported that acid hydrolysis method was used to extract collagen from skin trimming waste. For instance, Masilamani et al. [2] used propionic acid and acetic acid for solubilisation collagen from raw trimmings of goat skins. Compared with the commonly used acetic acid extraction, higher yield of collagen $(\sim 93 \%)$ was achieved by using propionic acid [2]. In order to prepare collagen or gelatin with high purity and low cost, two or more hydrolysis methods used in combination might be an alternative way.

\subsection{Application of collagen/gelatin}

For the applications of collagen or gelatin extracted from untanned solid waste, recent researches have been emphasized in the field of packaging, biomedicine and cosmetics. For instance, Masilamani et al. [59] prepared a kind of biodegradable packing material using gelatin (Gel) extracted from raw bovine skin trimmings by acetic acid. To overcome the drawback of high watersolubility of gelatin in packaging application, poly vinyl alcohol (PVA) was used to blend with the extracted gelatin for making composite films. After plasticizing and cross-linking with glycerol (Gly) and glutaraldehyde (GA), the optimized Gel/PVA/Gly/GA film showed excellent strength and sealing property similar to the control film of low density polyethylene (LDPE) [59].

Moreover, because of excellent biodegradability, affinity, low antigenicity and superior biocompatibility, recycled collagen has been successfully applied in biomedical field, such as, Yang et al. [60] using collagen extracted from pork skin by enzymatic hydrolysis to prepared collagen burn-healing membrane by adding scutellaria baicalensis. This novel porous membrane showed good biocompatibility and cell adaptability, anti-bacterial, anti-inflammatory and anti-allergy, which might be used as an ideal burnhealing material [60]. Fan et al. [61] modified collagen-chitosan (COL-CS) porous scaffolds by mixing nanometer titanium dioxide (nano- $\mathrm{TiO}_{2}$ ) to improve anti-bacterial property. The application of the prepared $\mathrm{TiO}_{2} / \mathrm{COL}-\mathrm{CS}$ composites in wound healing was investigated in vitro, demonstrating good permeability and humid environment [61]. Murali et al. [62] extracted collagen (C) from trimmed skin wastes using acetic acid and blended with starch (ST)/soy protein (SP) to prepare hybrid films (C/ $\mathrm{ST} / \mathrm{SP}$ ). The biocompatibility, physical and chemical properties of the as-prepared hybrid films were investigated, which showed improved performance compared with

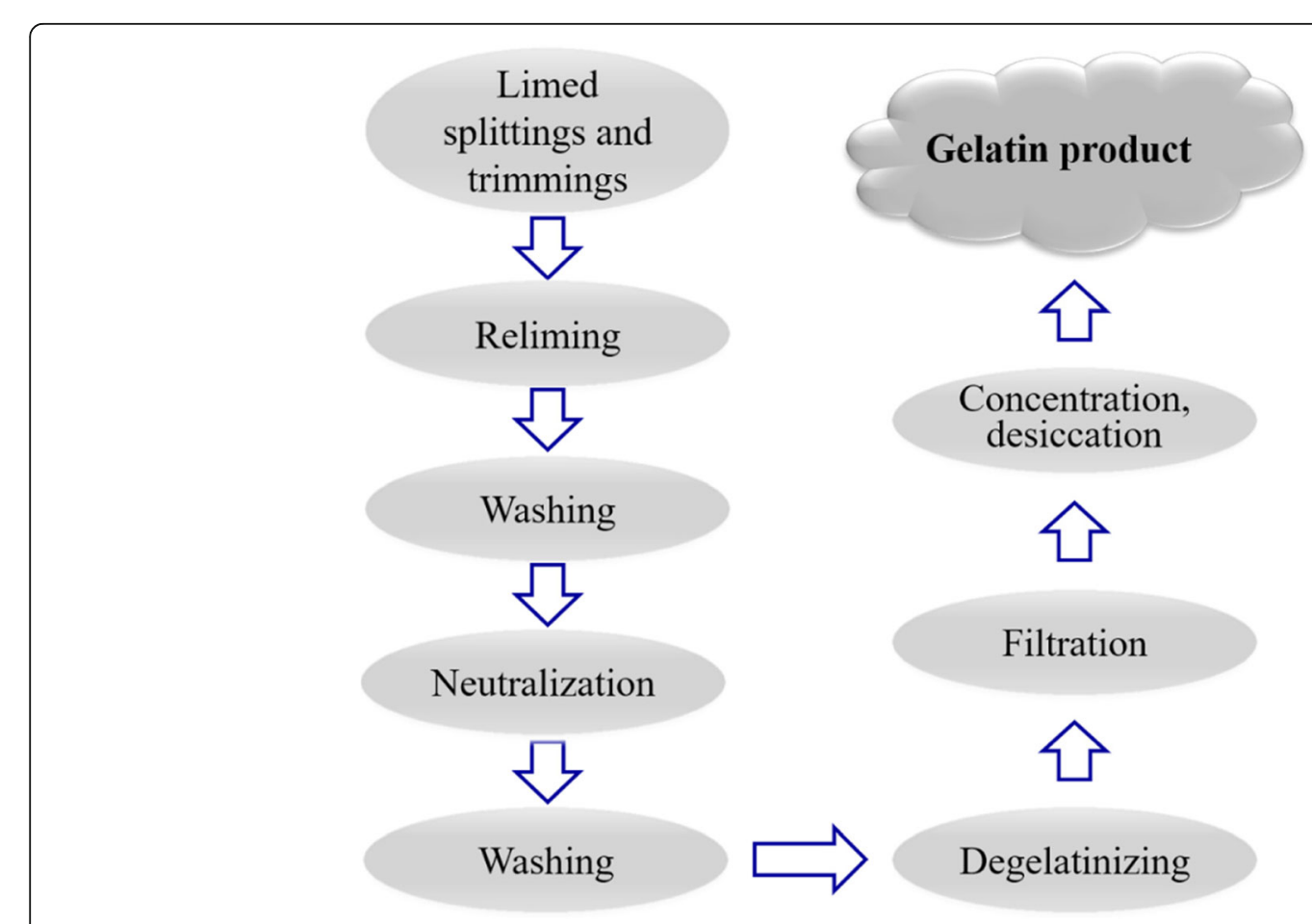

Fig. 2 The preparation processes of industrial gelatin by alkali hydrolysis 
pure collagen film. The extendibility and strength of the films increased with increasing the concentration of SP and ST in hybrid films, respectively. Moreover, the hybrid films also exhibited excellent biostability and biocompatibility by the equilibrium swelling, in vitro biodegradation and in vitro cytotoxicity studies [62].

The other application of collagen is as raw materials for cosmetic and cleaning products industry. Mendrycka et al. [63] produced emulsions containing different concentrations of collagen hydrolysates extracted by alkaline hydrolysis and enzymatic hydrolysis from calf skins. The properties of hydration, sensory, appearance rubbability and washability of the proposed emulsions were evaluated, confirming that the extracted collagen from hides can be used as an anti-ageing ingredient of cosmetic emulsions [63].

Otherwise, collagen can also be used to synthesize biocomposite and carbon material for the applications of adsorbent and energy. Thanikaivelan et al. [64] prepared magnetic nanocomposite of collagen from bovine hide trimming wastes and superparamagnetic iron oxide nanoparticles by simple process. The obtained nanobiocomposite were applied as adsorbent to remove oil from water by magnetic tracking. Then the oil adsorbed magnetic nanobiocomposite can be converted into carbon materials, which provided a new avenue for waste recycling [64]. Ashokkumar et al. [65] prepared multifunctional carbon nanomaterials using collagen extracted from skin trimmings by high temperature treatment. The obtained nanocarbons doped with nitrogen and oxygen had hexagonal graphitic structure with onionlike morphology, which potentially applied as $\mathrm{Li}$ ion battery electrodes [65].

\subsection{Utilization of grease waste residue}

According to statistics, about $70 \sim 230 \mathrm{~kg}$ fleshing waste produces by processing of one ton of raw hides, which contains about $87 \%$ water, $4 \sim 6 \%$ protein (dry weight), $1 \sim 2 \%$ fat (dry weight) and carbohydrates [66]. The general utilization of these fleshing wastes was to extract oils and fats, produce biofuel and prepare leather fatliquor.

The established methods for extracting oils and fats from fleshing wastes include soxhlet extraction, accelerated solvent extraction and supercritical fluid extraction. Nevertheless, the usage of toxic solvents and long operation time for these methods may cause secondary pollution for environment and human health, especially soxhlet extraction. Therefore, novel environment friendly extraction methods need to be developed. Devaraj et al. [67] developed acid/alkaline assisted fat extraction method for the industrial application without using organic solvent. The fleshing wastes contain $260 \mathrm{~g}$ fatty oil, by using acid hydrolysis method, $254 \mathrm{~g}$ fatty oil with extraction efficiency of $98 \%$ was attained which carried out with $4 \%$ of $\mathrm{H}_{2} \mathrm{SO}_{4}$ at $120^{\circ} \mathrm{C}$ for $1.5 \mathrm{~h}$. Whereas, acid hydrolysis assisted soxhlet process obtained $260 \mathrm{~g}$ fatty oil with $100 \%$ extraction efficiency at $80^{\circ} \mathrm{C}$ for $1.5 \mathrm{~h}$ using less solvent and time. Moreover, the physicochemical analysis of extracted fat oil showed that leather fleshing waste could be a potential raw material for biodiesel [67].

Fleshing wastes as biofuel can be used to produce biodiesel and biogas by anaerobic digestion [68-70]. Ma et al. [71] prepared ethanol-diesel emulsifier by using fatty acid methyl esters (FAME) from fleshing wastes. The properties of emulsifying, stability, dispersibility, burning rate and smog release rate for the prepared ethanoldiesel fuel were detailedly evaluated, revealing lower burning rate and smog release rate than $0^{\#}$ diesel fuel and excellent erosion resistance [71]. Aathika et al. [72] adopted limed fleshing co-digested with tannery sludge to produce biohydrogen by using anaerobic hydrogenation activity in a batch reactor. The effects on utilization of fleshing wastes for the generation of biohydrogen were studied and the cumulative bio-hydrogen yield significantly increased (higher than 8 times) under the optimized experimental conditions [72]. However, the sustainable production and storage of this promising energy carrier is still be a challenge.

The best resource utilization manner is to turn leather solid waste into products and recycled in leather making. For fleshing waste, one of the effective usage is to prepare leather fatliquor, such as, Nasr [73] prepared sulfate fatliquor from sheep limed fleshing wastes to be reused on small scale leather making. Fats were firstly extracted from fleshing waste by water vapor steam, which can be used to prepare sulphated fatliquor subsequently. The chemical properties of the extracted fats and sulphated fatliquor were estimated, indicating satisfactory fatty acids yield and stable performance. For the application in light and heavy leather processing, the quality of finished leather was comparable with that using commercial fish oil fatliquors [73].

\section{Resource utilization of chrome-containing leather solid waste}

During the chrome tanning process, enormous amounts of chromium containing leather solid wastes were generated including chrome shaving, splitting and trimming waste, which main compounds are trivalent chromium and collagen. As reported, the amount of chromium (mainly $\mathrm{Cr}_{2} \mathrm{O}_{3}$ ) of these leather wastes was about $1 \sim 3 \%$ and the collagen content was estimated to approximate $90 \%$ [74]. Because of the trivalent chromium can be easily oxidized to toxic hexavalent chromium under certain conditions, the chromium pollution of leather solid wastes urgently needed to be treated. Nowadays, researches focus on developing effective resource utilization technologies 
for reusing chrome-containing leather wastes, which can be classified to direct utilization and indirect utilization. As shown in Fig. 3, direct utilization means that chrome-containing leather solid wastes were applied in the preparation of electrostatic flocking, regenerated fiber leather, adsorbents and conductive materials by simple treatment. Indirect utilization included two approaches, one was recovering chromium from chrome-containing leather solid wastes which was applied as pigments or recycled into leather making process, and the other was extraction of collagen or gelatin from chrome-containing leather wastes after dechroming treatment which was applied in leather making, papermaking, agricultural and biomedical field.

\subsection{Direct resource utilization}

Researches have been proved that one of the viable methods for resource utilization of chrome-containing leather solid waste was applied as potential materials for electrostatic flocking, regenerated leather, adsorbents and conductive materials by simple treatment steps without dechroming. Among these applications, developing methods for decreasing the solubility of $\mathrm{Cr}$ from leather and avoiding $\mathrm{Cr}$ leaching is still a concern issue.

Leather fine fiber obtained from chrome-containing leather shavings by mechanically smashing can be applied to produce synthetic leather by electrostatic flocking technology. However, leather fine fiber has poor rise in static electric field without treatment by scouring agent. In order to achieve excellent flocking effect, Liu et al. [75] used scouring agent consisted of alumia sol, ludox, sodium chloride and aluminium potassium sulfate to improve the rise property of leather fine fiber in static electric field. The usage of inorganic salt can improve the electrical conductivity of leather fluff and increase flocking density. Alumia sol and ludox were used as antistatic agent and disperser respectively, which can facilitate inorganic salt adsorbed on the surface of leather fluff. Moreover, the formula of scouring agent was also optimized and the results showed that the content of alumia sol and sodium chloride significantly influenced the flocking effect [75].

The commonly used preparation procedure of regenerated leather from chrome shavings was summarized as follows. Chrome shavings were firstly soaked with the expansion softener, subsequently produce leather fibers by pulping or mechanical pulverization. Then, the regenerated leather was prepared by adding binder, compressing and leather finishing. Ding et al. [76] proposed an efficient method for the preparation of regenerated leather by using chrome shavings and the preparation process was shown in Fig. 4. The results demonstrated that the prepared regenerated leather can be an alternative to splitted leather [76]. To improve the poor mechanical properties of collagen fibers, Ding et al. [77] prepared regenerated leather billet (semi-finished product) by using chrome-tanned leather shavings and waterborne polyurethane (WPU) as raw materials, which showed high tensile strength, thermal stability and heat storage ability, attributed to the hydrogen bonds and entanglement between WPU and leather shavings [77].

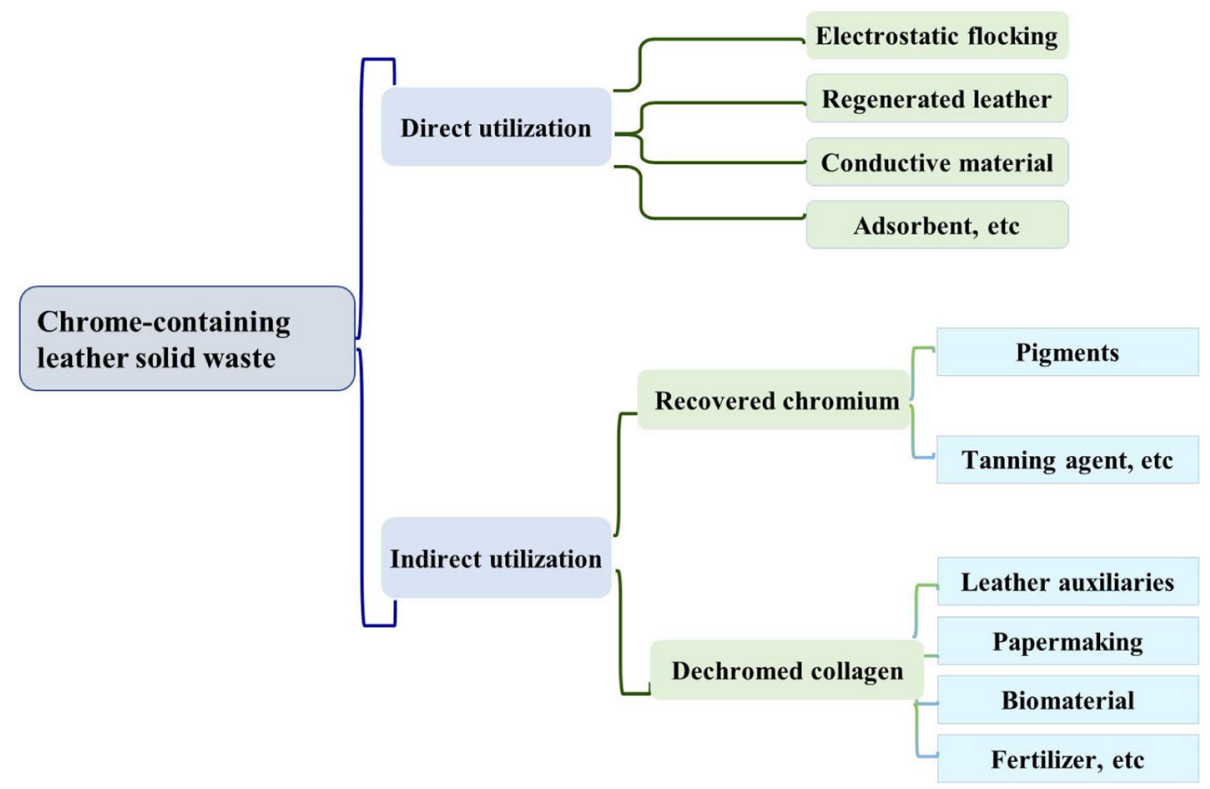

Fig. 3 Resource utilization of chrome-containing leather solid waste 


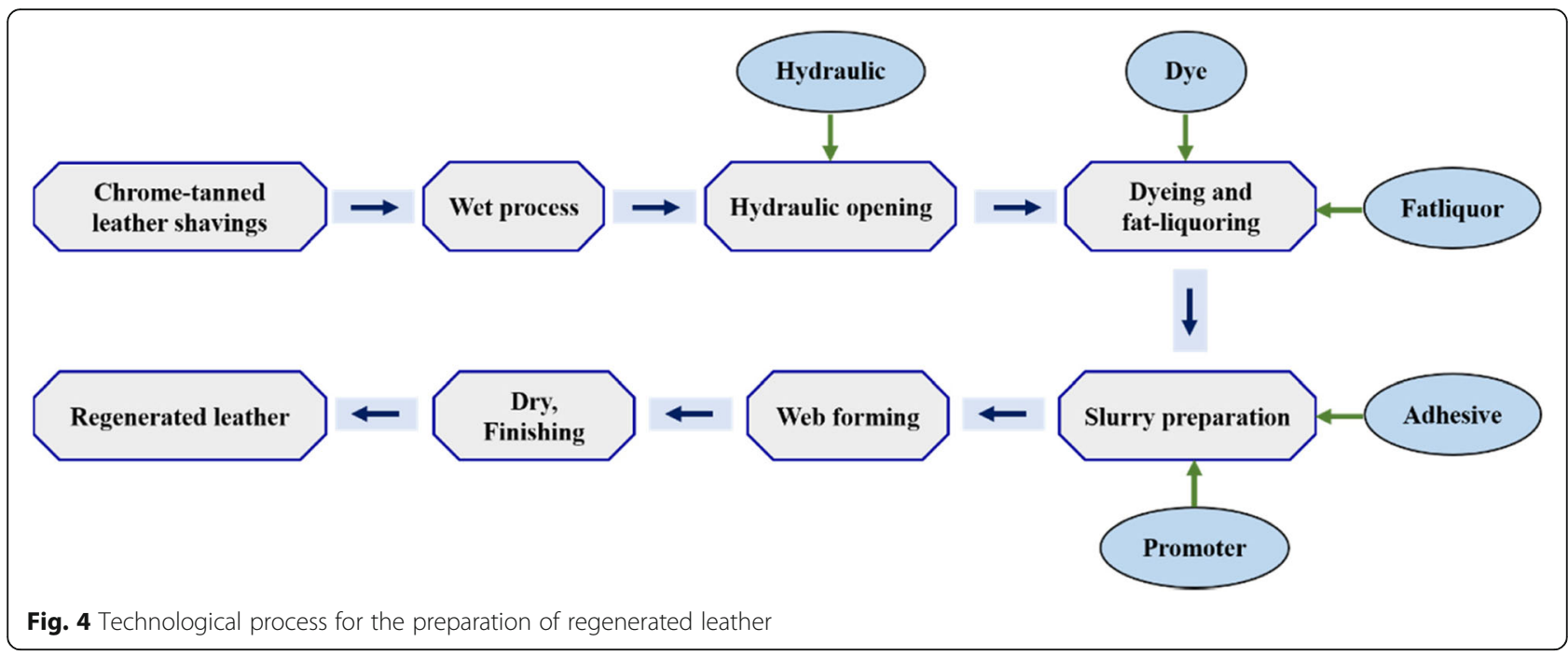

The preparation of conductive materials from chrome-containing leather waste is another direct utilization manner, such as, energy storage devices, semiconductors, and electrocatalysts. Recent studies focused on producing carbon materials by heating, for instance, Konikkara's group [78, 79] used crust leather waste as precursors to prepare kinds of hierarchical porous carbons (HPC) at relatively high temperature by using pre-carbonization and chemical activation methods. Due to high specific capacitance and electrochemical cycle stability, these leather waste carbon materials can be used to fabricate supercapacitors. Lardizabal-Guitierrez et al. [80] synthesized electrocatalysts using chromium-containing leather waste as raw material by simple thermochemical treatment. After pyrolysis treatment of leather, the relative carbon content increased, providing the electrical conductivity of the as-prepared material.

Recycling usage of chrome-containing leather waste as adsorbent for removal organic and inorganic pollutants has been proved to be a feasible method, which have successfully applied to adsorb $\mathrm{As}(\mathrm{V})$ [81], Cr (VI) [82, 83], Cr (III) [84], U (VI) [85], Pb (II) [86], tannis [87] and organic dyes [88]. For instance, to obtain high adsorption capacity, Luo's group $[85,86]$ activated chrome-tanned leather waste by $\mathrm{NaOH}$ to prepare alkali-activated porous leather particles and applied to adsorb $\mathrm{U}(\mathrm{VI})$ and $\mathrm{Pb}(\mathrm{II})$. To investigate the application in industrial tannery wastewater treatment, Piccin's group $[89,90]$ employed chrome-tanned leather shaving waste as adsorbent to remove Acid Red 357 in dyeing wastewater from pilot-scale processing of leather. Parameters effecting adsorption efficiency were detailed studied, showing satisfactory removal efficiency and relative high adsorption capacity. The proposed adsorption method represented an appropriate guidance for the tanning industry by recycling leather waste in tannery wastewater treatment.

\subsection{Indirect resource utilization}

The intelligently indirect resource utilization of chrome-containing solid wastes commonly included recovered chromium and extraction of collagen or gelatin after dechroming treatment. Chromium of chrome-containing solid wastes can be recovered by thermal treatment [91], alkaline hydrolysis [92], biochemical method [93, 94] and oxidation method [95], subsequently applied in the preparation of pigments or recycled into leather making process as tanning/ retanning agents [96-98]. For instance, Da Costa Cunha et al. [99] used natural organic matter (NOM)rich water as a gelification agent for the manufacture of ceramic nanopigments, which consisted of $\alpha$-alumina doped with recycled chromium ions from liquid and solid tannery wastes. The as-prepared $\mathrm{Cr}-\mathrm{Al}_{2} \mathrm{O}_{3}$ was also used as catalysts for the reduction of 4-nitrophenol. Several conditions of the preparation of $\mathrm{Cr}-\mathrm{Al}_{2} \mathrm{O}_{3}$ were detailed evaluated, and the results showed that the solid tannery waste was more suitable for the usage of ceramic pigments compared to liquid waste. Moreover, the leaching tests indicated that no significant concentration of chromium (below $0.002 \mu \mathrm{g} \mathrm{L}^{-1}$ ) were detected [99].

Considering the high collagen contents of chromecontaining leather solid wastes, extraction and reusage of collagen or gelatin were the most significant method. Moreover, to eliminate the influence of chrome and extract available collagen or gelatin from chrome-tanned leather wastes, dechroming is the key focus and effective methods have been developed. In this section, we focused on the review of dechroming methods and the applications of dechromed collagen/gelatin. 


\subsubsection{Dechroming and extraction of collagen/gelatin}

With respect to the simplified direct utilization, indirect utilization of chrome-containing leather waste by dechroming and extraction of collagen/gelatin is more complicated, mainly concentrating in the separation of chromium and collagen into two or more portions step by step. In the following paragraphs, dechroming methods established with high dechromisation efficiency and broad application have been introduced, such as, acid hydrolysis dechroming, alkali hydrolysis dechroming, enzymatic hydrolysis dechroming and oxidation dechroming.

Acid hydrolysis dechroming method generally used strong acids to treat leather waste, in which $\mathrm{Cr}$ (III) combined with the functional group of strong acid was turned into soluble complex and simultaneously releasing the collagen. Typically, some kinds of inorganic and organic acids were used including sulphuric acid, hydrochloric acid, phosphoric acid, oxalic acid, formic acid and citric acid. For instance, Ferreira et al. [100] used sulfuric acid to remove chromium from chromium-containing leather waste at low temperature condition. The results showed that the dechroming efficiency can be around $30 \% \sim 60 \%$ by treating with $4 \%$ sulfuric acid at the temperature of $293 \sim 313 \mathrm{~K}$. Although acid hydrolysis dechroming method has relatively high dechromisation efficiency, the potential problems of corrosion and collagen hydrolysis should not be ignored.

To modify the acid corrosion problem, alkali hydrolysis dechroming method was proposed using $\mathrm{CaO}, \mathrm{MgO}$ or $\mathrm{NaOH}[101,102]$ to dissolve $\mathrm{Cr}$ (III), which will be precipitated from collagen by alkali to form insoluble $\mathrm{Cr}(\mathrm{OH})_{3}$ sediment. Among the commonly used alkalic reagents, $\mathrm{CaO}$ is the cheapest and most readily available one, which has been applied in industrial production with high hydrolysis effect. However, high content of $\mathrm{Ca}^{2+}$ in the extracted collagen solution and chromium sludge reduced its reusage value. In order to solve these problems, Holloway et al. [103] dissolved chrome sludge after dechromisation with sulfuric acid and further produced leather tanning agent. Su et al. [104] pretreated the chromium-containing leather scrap with $\mathrm{NaOH}$ $120^{\circ} \mathrm{C}$ for $4 \mathrm{~h}$ and extracted the collagen with high extraction efficiency (88.98\%). Ding et al. [105] developed a mild acid-alkali alternate treatment with high dechroming level and low hydrolysis degree of collagen by four steps using $\mathrm{NaOH}$, urea, sulfuric acid, $\mathrm{Ca}$ $(\mathrm{OH})_{2}$ and sulfuric acid, which showed high dechroming efficiency over $97 \%$ and low collagen hydrolysis degree $(10 \%)$.

Enzymatic hydrolysis dechroming method as an environmentally friendly method was proposed to reduce secondary pollution and hydrolyse collagen into small peptide molecules and amino acids, which has the advantages of strong specificity, mild reaction condition and low energy consumption. Compared with acid or alkali hydrolysis method, the dechroming and collagen extraction efficiency of enzymatic hydrolysis were relatively lower, which needed to be improved. The combination of two or more dechroming methods has been developed to increase dechroming efficiency. For instance, Zhou et al. [106] combined alkali hydrolysis and enzymatic hydrolysis dechroming method to remove chrome and extract collagen from chrome shavings. Three kinds of protease were optimized including AS1. 398 neutral protease, 2709 alkaline protease and industrial trypsin. By evaluation and comparison of the dechroming and collagen extraction efficiency, the combination of $\mathrm{CaO}$ and industrial trypsin is more suitable for dechromisation and extraction of collagen from chrome shavings in industrial production.

Oxidation dechroming carried out using peroxide compounds to convert $\mathrm{Cr}$ (III) into the soluble $\mathrm{Cr}$ (VI) in weak alkaline solution and simultaneously separate collagen from chrome-containing leather solid waste. Yuan et al. [107] used oxidation dechroming method to treat chrome shavings with $13 \% \mathrm{H}_{2} \mathrm{O}_{2}$ and $3.2 \% \mathrm{NaOH}$ at $50^{\circ} \mathrm{C}$ for $30 \mathrm{~min}$, and the dechromisation efficiency reached $97.39 \%$ after four times dechromisation. Chen et al. [108] studied alkali-oxidation-acid method to remove chrome from chrome shavings. The orthogonal experiments were adopted to optimize the dechromisation conditions by using $\mathrm{NaHCO}_{3}, \mathrm{H}_{2} \mathrm{O}_{2}$, sodium oxalate and oxalic acid and the final dechromisation efficiency was attained of $95.65 \%$ by treatment three times [108]. However, toxic $\mathrm{Cr}$ (VI) can be created during the procedure of oxidation dechroming, easily causing secondary pollution. Developing novel alternative dechroming methods will be urgent and some innovation methods have been proposed, such as, pyrolysis $[109,110]$ and biochar dechroming [111].

\subsubsection{Utilization of dechromed collagen/gelatin}

Dechromed collagen obtained from chrome-containing leather solid wastes have been applied in leather process, such as retanning filling materials [112-114] and finishing agents $[115,116]$, papermaking, such as sizing agents, flocculant and surfactant $[117,118]$, agricultural production, such as liquid mulch film, amino acid foliar fertilizer, emulsifier of pesticides [119-121] and biomedical field [122-124].

A significant option would be reusage of dechromed collagen for value added application in leather processing, which can be used to the production of retanning and finishing agents. Shakilanishi et al. [125] applied collagen hydrolysate from chrome shaving to produce dehairing protease for usage in cleaner 
leather processing. The fluoresence spectral results confirmed that collagen hydrolysate stabilized the enzyme and prolonged its activity. Ramalingam et al. [126] prepared hybrid composite by mixing collagen hydrolysates from leather waste with degraded black liquor from the paper and pulp industry, which was applied as retanning agent during the post tanning process. The characterised composites can effectively improve the strength and softness of the finishing leather and promote the uptake of dye [126]. Tang et al. [127] used polyurethane modified collagen hydrolysate to prepare finishing agent, which showed good fracture elongation and extensibility. Li's group also produced a series of collagen-based composites as retanning agents, and good sensory and mechanical properties of the finishing leather was achieved.

The production of sizing agents in the paper industry by adding collagen hydrolyzate can significantly improve the strength and breakage index of paper. Wang's group $[128,129]$ prepared vinyl modified sizing agent by emulsion polymerization using collagen hydrolysate as raw materials. The applied experimental results showed that the tensile and tearing strength of paper was significantly enhanced. Ocak [130] prepared composite film using collagen hydrolysate from leather solid waste and chitosan to apply in packaging and wrapping purposes. With the increasing of chitson concentration, the thickness, tensile strength, elasticity modulus and water vapor permeability of the film obviously increased.

Besides, Pati et al. [131] employed purified protein hydrolysate from chrome-tanned leather waste in formulation of fertilizer, which was used as nitrogen source for the production of soybean. Compared with the commercial fertilizer, similar productivity of the soybean plant was attained. The same group also used the dechromed protein hydrolysate to produce poultry feed and partially replace soyabean meal as a sole protein source for growing broiler chickens [132]. The results demonstrated that up to $75 \%$ of soyabean meal can be displaced by protein hydrolysate with no obvious influence of growth performance or meat characteristics. Nogueira et al. [133] used dechromed collagen from wet blue leather to adsorb phosphorus (P) and potassium (K) as $\mathrm{N}_{\text {collagen }} \mathrm{PK}$ fertilizer. The materials with and without the addition of $\mathrm{P}$ and $\mathrm{K}$ were characterized, and Langmuir, Freundlich adsorption models were used to analyze the adsorption experimental data. The $\mathrm{P}$ and $\mathrm{K}$ adsorption on collagen were proved to be an interesting alternative as NPK fertilizer [133].

Recently, plenty of innovation applications of dechromed collagen or gelatin have been reported. For instance, Dang et al. [134] used gelatin extracted from leather solid waste by alkaline hydrolysis as raw material to synthesize copolymer grafted with acrylamide and acrylic acid by free radical copolymerization, which applied in chemical sand-fixation. The as-prepared copolymer with excellent biodegradability can be combined with sand particles, showing good water retention, anti-wind erosion and anti-water erosion. Gil's group applied dechromed collagen in biomedical, such as, using polyurethane microcapsules containing diisocyanates as healing agent to improve self-healing properties of collagen obtained from chrome-containing leather waste [135], employing chrome-free protein as a slow-release drug carrier in skin treatment [122].

\section{Resource utilization of tannery sludge}

Tannery sludge (TS) is another solid waste generated from the procedure of leather making and treatment of tannery wastewater, which mainly contains amount of sulfide, chromium, blood, oil, lime, dissolved hair and protein. Because of high concentration of sulfide, chromium and harmful bacteria, tannery sludge was classified as hazardous solid waste. To avoid the possible harm for human health and environment, much more attention should be paid on the methods to deal with it. However, the traditional disposal methods like landfill, incineration and stacking can not thoroughly eliminate the hazard and easily cause secondary pollution. Nowadays, developing efficient recycling methods might be the best choice to both eliminate the potential pollution and fully reuse of the available ingredient of TS. And some recycling methods have been reported by recent studies, such as, compost, anaerobic digestion, preparation of building materials, oil and adsorbent.

\subsection{Biocomposting}

Tannery sludge contains a lot of organic matter and nutrients, which are good fertilizer for plant growth. But the exist of hazardous heavy metals and bacteria, biocomposting by means of ripening the organic matter and killing the pathogenic microorganisms was used to displace of directly usage. However, the heavy metals in TS limit its usage as composting feed or bulking agents for the preparation of compost. To decrease the heavy metal concentration in the compost and increase its nutrient components, recent research works focus on the co-composting of TS with other materials. For instance, Karak et al. [136] investigated and compared the performance of composts produced from human hair with different solid waste including cow dung, municipal solid waste, pond sediment and TS. By the addition of human hairs, the heavy metal contaminations were significantly higher than the control but lower than the Indian permissible value [136].

Although some studies evaluated that composting using TS had excellent plant growth-promoting properties, the influence of chromium in composting for environment or human health is still uncertain. Therefore, 
chromium in composting should be fully removed from tannery sludge before using as agricultural fertilizer.

\subsection{Anaerobic digestion}

The other usage of the organic matter from tannery sludge is anaerobic digestion, which can convert biodegradable organic matter into biogas. Recently, researchers focus on the improvement of digestion performance by the addition of enzyme. For instance, Kameswari et al. [137] carried out co-digestion studies for biogas generation using fleshing and sludge from the treatment tannery wastewater as substrate. During the procedure of co-digestion, lipase was added to improve the rate-limiting step of hydrolysis in anaerobic digestion procedure. Comparing with the control group without adding lipase, the results indicated that the biogas generation increased about $15 \%$ and the digestion period was reduced about 30\% [137]. Chen et al. [138] proposed a pretreatment method for anaerobic digestion of tannery sludge to increase the yield of biogas by adding enzyme. Based on the recent studies, it was found that anaerobic digestion needed long period, and the utilization efficiency of sludge and the yield of biogas were low [138].

\subsection{Building materials}

For the preparation of building materials, chromium in tannery sludge was immobilized to reduce its toxicity. Until now, many kinds of building materials have been produced from TS, such as, brick, aggregate and lightweight ceramsite. The phenomenon of chromium leaching is also the predominant focus. Among these materials, brick-making from TS was the commonly disposal way with the advantages of simple and low cost. For instance, Juel et al. [139] prepared clay bricks with different TS contents and evaluated the feasibility of using these bricks as building materials by the parameters of strength, water absorption, shrinkage rate, ignition weight loss and bulk density. The experimental results showed that this proposed method can produce excellent quality bricks and their mechanical and physical properties can achieve ASTM and BDS standards [139]. However, chromium in bricks might be leached gradually after using many years, which can cause the secondary pollution.

Another way to effectively use tannery sludge is to use it as a lightweight ceramsite, which has the advantages of lightweight, high strength, thermal insulation, and shock resistance. Li's group [140] sintered lightweight ceramsite by strictly controlling the ratio of ordinary clay to tannery sludge at $1130 \sim 1800{ }^{\circ} \mathrm{C}$ for $20 \mathrm{~min}$. The obtained bulk density of ceramsite was between 600 1500 $\mathrm{kg} / \mathrm{m}^{3}$ and low chromium leaching was accomplished meeting the national standards of ceramsite [140].

\subsection{Preparation of oil and adsorbent}

With the development of sludge heat treatment technology, tannery sludge can be used to prepare oil and adsorbent after pyrolysis. For the preparation of oil, Li et al. [141] evaluated the effects of three sodium salt catalysts on the preparation of oil derived from the pyrolysis of tannery sludge. By characterized the performance of these oil using thermogravimetric and GC/MS, the chemical components of these obtained oil products was similar to biodiese [141]. For the preparation of adsorbents, Geethakkarthi et al. [142] prepared activated carbon from tannery sludge by a combination of physical and chemical activation, which was applied in removal of azo reactive dyes. The achieved adsorbent had a high BET surface area $\left(188.25 \mathrm{~m}^{2} / \mathrm{g}\right)$ and strong binding ability to the anionic azo dyes [142].

\section{Resource utilization of finished leather waste}

Finished leather wastes are commonly generated from tanneries and leather products industries, which mainly includes leather trimmings, crust leather buffing dust and finished leather scraps. Amongst them, the bulk of used leather products are considered as the major solid wastes, such as shoes, bags and end products of leather industry. According to the latest estimates, 20 30\% leather is discarded as waste in the production of footwear. However, due to the difficulty for disposing, majority of these leather wastes are directly discarded without proper treatment, which might cause environmental pollution. To solve this problem, some governmental policies and regulations are needed. Moreover, it is urgency to establish feasible and economical recycling methods of finished leather wastes for reducing environmental pollution.

Up to now, researchers devote a number of efforts to search for efficient reused methods, which mainly includes producing regenerated leather composites and blended fabrics using physical or chemical methods. Based on the advantages of low cost, excellent mechanical property, high specific strength, environment friendly and bio-degradability of plant fibers (PFs), recent studies mainly focus on their application in the preparation of regenerated leather composites. For instance, Teklay et al. [143] prepared recycled leather PFs composite boards by mixing leather fibers from finished leather waste with different kinds of PFs, such as jute, hibiscus, sisal, palm and enset. Compared with the recycled leather (RCL), the as-prepared RCL-PFs composite boards showed better tensile strength, which might be used as raw material for the preparation of light consumer goods [143]. Senthil et al. [144] produced regenerated leather composites (RLCs) by incorporating plant fibers into regenerated leather which was prepared from used leather products. For the preparation of RLCs, 
to enhance its mechanical properties, different kinds of PFs were used, including coconut fibers (CTF), sugarcane fibers, banana fibers and corn fibers. The indexes of tensile strength, elongation at break, tearing strength, water desorption and flexibility for these prepared RLCs were evaluated and excellent performance was exhibited by using leather fiber/CTF (50:40 ratio). Moreover, these prepared RLCs have promising application values in footwear and leather goods industry [144]. Besides, the same group [145] used leather fibers extracted from finished leather wastes mixing with cotton fiber and polyester fiber to prepare composites, which were subsequently produced leather blended yarns (LBYs) and leather blended fabric (LBFs). Physicochemical properties of the prepared fabrics were seriously assessed, such as extension at break, single yarn strength, thickness, needle perforations and water vapour permeability. In addition, $\mathrm{ZnO}$ nanoparticles were coated onto these prepared fibers to improve their antibacterial activity.

\section{Conclusions and perspectives}

In this review, the current status of resource utilization of leather solid waste generated from chrome tanning was summarized focusing on the published studies in recent decade, concerning the improved treatment techniques and various applications of tannery hair waste, untanned solid waste, chrome-containing leather solid waste, tannery sludge and finished leather waste. Although worldwide scholars and engineers devoted a lot of efforts on the development and improvement of reusage technologies, the resource utilization of tannery solid waste still faced kinds of challenges and opportunities. The problems and possible solution strategies were proposed as follows. And we believe that the sustained attention and researches will promote the resource utilization of leather solid waste to achieve large-scale industrialization.

\subsection{The extraction and application of keratin}

The commonly used extraction methods of keratin, such as oxidation, reduction, acid and alkali hydrolysis, mostly required complex extraction, purification process, long operation time and high energy consumption. Moreover, it is tough to control the purity and relative molecular weight of the extracted keratin. Although the novel enzymatic hydrolysis with the advantages of mild reaction condition and environmental friend was proposed, it also needs high cost and long reaction time increasing the difficulty of industrialization. Except that, the extensive usage of acid and alkali increases water treatment difficulty and causes secondary pollution. To solve these drawbacks and problems, extraction methods of keratin should be improved and developed by using less or no toxic solvents, simple operation steps and low cost, such as, high density steam flash-explosion technology, ionic liquid extraction and deep eutectic solvent extraction method.

Recent studies showed that the extracted keratin mainly applied in biomedical, leather making and adsorption materials. However, keratin in biomedical application was still in laboratory research stage, and no products were applied in clinic. For the leather making application, current products mainly used the vinyl monomer to modify keratin to prepare protein filling agents. Therefore, developing novel modification methods and smart technologies of utilizing keratin on the basis of keratin's specific nature were feasible strategies for further research.

\subsection{Untanned solid waste and chrome-containing leather solid waste}

The preparation of industrial gelatin was the most important application for untanned solid waste. The China national standard method (GB/T 6783-2013) also regulated that trimming waste of raw hide and splitted liming skin can be used as raw materials to produce edible gelatin. However, the safety assessment of edible gelatin should be paid more attention, because of the existence of toxic sulfide and some bacteria in hide or skin scraps.

Using suitable dechroming methods to remove chrome from chrome-containing leather solid waste was another research hotspot. For the proposed methods, more or less drawbacks still need to be improved. The dechroming process of oxidation dechromisation needed to be performed many times to attain satisfy efficiency. Acid hydrolysis also has the disadvantages of severe hydrolysis of collagen and time consuming. The amino acid containing hydroxyl and amide group can be destroyed by using alkali hydrolysis, which also need long treatment time. Enzymatic hydrolysis needed specific species of enzyme and high cost, meaning that it is difficult to industrialize. In order to improve the dechromisation efficiency, ultrasonic technique can be simultaneously used during the procedure of these dechromisation treatment. Combination of acid hydrolysis, alkali hydrolysis and enzymatic hydrolysis might be significant increasing the yield of collagen and decreasing the cost. The development of protease with high chromium tolerance and low cost was also a potential way.

Chrome shavings directly applied as adsorbent have also widely used, which can simply and effectively remove pollutants in wastewater. However, practicable and valid treatment of adsorbents adsorbed contaminants, the desorption and resuage of the adsorbed pollutants from adsorbents were still urgently to be solved. 


\subsection{Tannery sludge}

Tannery sludge as an available resource has been successfully applied in biocomposting, anaerobic digestion, preparation of building materials, oil and adsorbent. Many studies have proved that anaerobic digestion needed long period with low utilization efficiency and biogas yield. And chromium leaching is the predominant problem in biocomposting and building materials applications.

Considering the possible secondary pollution, developing efficient recycling methods and originally controlling the production of tannery sludge might be alternative choice, such as, in-situ sludge reduction technology, mixing sludge with clay to sinter ceramsite avoiding the leaching of chrome, adding enzyme to enhance the digestion performance of anaerobic digestion method.

\subsection{Finished leather waste}

Based on the complicated property of finished leather waste, most of them were discarded without explicit classification and appropriate treatment. As for the resource utilization, producing regenerated leather composites and blended fabrics were two major treatment ways. Except that, other feasible manners of finished leather waste reusage were seldom reported.

Although different kinds of plant fibers were incorporated to prepare regenerated leather, the mechanical property should also need to be improved. Otherwise, there is a perceived potential value to reuse the leather finished solid waste to make leather art crafts. Therefore, considering the life cycle assessment (LCA), long-term efforts should be paid to originally control the production of solid waste, develop versatile technologies and strategies for reusage the leather solid wastes into leather processing and make them applicable to market requirement.

\section{Abbreviations}

$[\mathrm{BMIM}]^{+} \mathrm{Cl}^{-}$: 1-butyl-3-methylimidazolium chloride; ${ }^{13} \mathrm{C}$ NMR: Solid state nuclear magnetic resonance; APDT: Antimicrobial photodynamic therapy; ATR-FTIR: Fourier transform infrared spectroscopy with attenuated total reflection technology; BOD: Biochemical oxygen demand; C: Collagen; CEL: Cellulose; CEL/CS + KER: Cellulose and/or chitosan -keratin composites; CNC: Cellulose nanocrystal; COD: Chemical oxygen demand; COLCS: Collagen-chitosan; CPX: Ciprofloxacin; CS: Chitosan; CTF: Coconut fibers; DES: Deep eutectic solvent; DOX-KNPs: Doxorubicin/keratin nanoparticles; DOX-KNPs-Agg: Aggregation prepared DOX-KNPs; DOX-KNPs-IG: Ionic gelation prepared DOX-KNPs; FAME: Fatty acid methyl esters; GA: Glutaraldehyde; GC/MS: Gas chromatography/mass spectrometry; Gel: Gelatin; GLY: Glycerol; HBA: Hydrogen bond acceptors; HBD: Hydrogen bond donors; HKVPA6: Hydrolyzed keratin/polyamide 6; HPC: Hierarchical porous carbons; HPFA: Hair protein filling agent; IL: Ionic liquid; KER: Keratin; LBFs: Leather blended fabric; LBYs: Leather blended yarns; LCA: Life cycle assessment; LDPE: Low density polyethylene; $\mathrm{Nano}^{-\mathrm{TiO}_{2}}$ : Nanometer titanium dioxide; NOM : Natural organic matter; PFs: Plant fibers; PVA: Poly vinyl alcohol; RCL: Recycled leather; RCLs: Regenerated leather composites; ROS: Reactive oxygen species; SP: Soy protein; ST: Starch; TDS: Total dissolved solids; TS: Tannery sludge; WPU: Waterborne polyurethane; XRD: X-ray diffraction
}

\section{Acknowledgements}

This work was financially supported by National Key Research and Development Program of China (No.2017YFB0308402). Shandong Provincial Key Research \& Development Project (No.2018GGX108006).

\section{Authors' contributions}

Yanchun Li made substantial contributions to conception and design of this review, and wrote section 6 "Recirculation of finished leather waste". Ruijun Guo collected references and wrote the initial draft. Wenhui Lu critically revised the article for important intellectual content, wrote section 7 "Conclusions and perspectives", and designed Fig. 2, Fig. 3, Fig. 4. Deyi Zhu gave final approval of this article, collected important references and designed graphical abstract. All authors read and approved the final manuscript.

\section{Authors' information}

Yanchun Li received her PhD degree in leather chemistry and engineering from Sichuan University, China, in 2001. She joined Qilu University of Technology (Shandong Academy of Sciences) in 1989 and promoted as a professor in 2000. Her research interests include resource utilization of leather solid waste, theoretical and technological studies of clean leather manufacturing technology.

Ruijun Guo received his BS degree in environmental engineering from Qilu University of Technology (Shandong Academy of Sciences), China, in 2017, and in the same year he joined leather chemistry and engineering of the same university as a master candidate. His current research interest is clean technology of leather manufacture and environmental protection. Wenhui Lu received her PhD degree in leather chemistry and engineering from Sichuan University, China, in 2017. She joined Qilu University of Technology (Shandong Academy of Sciences) as a lecturer in 2018. Her current research interests focus on the preparation of functionalized adsorbents and their applications in sample pretreatment and pollutant removal.

Deyi Zhu received his $\mathrm{PhD}$ degree in biomass chemistry and engineering from Sichuan University, China, in 2017. He joined Qilu University of Technology (Shandong Academy of Sciences) in 2005 and promoted as an associate professor in 2016. His research interest is resource utilization of leather solid waste.

\section{Funding}

National Key Research and Development Program of China (No.2017YFB0308402).

Shandong Provincial Key Research \& Development Project (No.2018GGX108006).

\section{Availability of data and materials}

Not applicable.

\section{Competing interests}

The authors declare that they have no competing interests.

Received: 11 February 2019 Accepted: 16 July 2019

Published online: 02 August 2019

\section{References}

1. Kanagaraj J, Senthilvelan T, Panda RC, Kavitha S. Eco-friendly waste management strategies for greener environment towards sustainable development in leather industry: a comprehensive review. J Clean Prod. 2015:89:1-17.

2. Masilamani D, Madhan B, Shanmugam G, Palanivel S, Narayan B. Extraction of collagen from raw trimming wastes of tannery: a waste to wealth approach. J Clean Prod. 2016;113:338-44.

3. Rajamani S.G. (2012). Recent developments in cleaner production and environment protection in world leather sector. ICAMS 2012-4 ${ }^{\text {th }}$ international conference on advanced materials and systems.

4. Wang B, Lin W, Ma CH, Zhang MR. Recovery of leather waste materials basis, present and future situation of utilization of collagen. Leather Chemicals. 2001;18(3):10-4

5. Kumaraguru S, Sastry TP, Rose C. Hydrolysis of tannery: fleshings using pancreatic enzymes: a biotechnological tool for solid waste management. J Am Leather Chem Assoc. 1998;93(2):32-9. 
6. Rouse JG, Van Dyke ME. A review of keratin-based biomaterials for biomedical applications. Materials. 2010;3(2):999-1014.

7. Shavandi A, Silva TH, Bekhit AA, Bekhit AEA. Keratin: dissolution, extraction and biomedical application. Biomaterials Science. 2017:5(9):1699-735.

8. Sundar VJ, Raghavarao J, Muralidharan C, Mandal AB. Recovery and utilization of chromium-tanned Proteinous wastes of leather making: A review. Crit Rev Environ Sci Technol. 2011;41(22):2048-75.

9. Jiang H, Liu J, Han W. The status and developments of leather solid waste treatment: A mini-review. Waste Manag Res. 2016;34(5):399-408.

10. Saran S, Mahajan RV, Kaushik R, Isar J, Saxena RK. Enzyme mediated beam house operations of leather industry: a needed step towards greener technology. J Clean Prod. 2013:54:315-22.

11. Wang B, Yang W, McKittrick J, Meyers MA. Keratin: structure, mechanical properties, occurrence in biological organisms, and efforts at bioinspiration. Prog Mater Sci. 2016;76:229-318.

12. Wang $D$, Yang $X H$, Tang RC, Yao F. Extraction of keratin from rabbit hair by a deep eutectic solvent and its characterization. Polymers. 2018;10(9):993.

13. Yamauchi K, Yamauchi A, Kusunoki T, Kohda A, Konishi Y. Preparation of stable aqueous solution of keratins, and physiochemical and biodegradational properties of films. J Biomed Mater Res. 1996;31(4):439-44.

14. Buchanan JH. A cystine-rich protein fraction from oxidized a-keratin. Biochem J. 1977;167(2):489-91.

15. Zhang J, Li Y, Li J, Zhao Z, Liu X, Li Z, Chen A. Isolation and characterization of biofunctional keratin particles extracted from wool wastes. Powder Technol. 2013;246:356-62.

16. Kurbanoglu EB, Kurbanoglu NI. Ram horn hydrolysate as enhancer of xanthan production in batch culture of Xanthomonas campestris EBK-4 isolate. Process Biochem. 2007:42(7):1146-9.

17. Aluigi A, Zoccola M, Vineis C, Tonin C, Ferrero F, Canetti M. Study on the structure and properties of wool keratin regenerated from formic acid. Int J Biol Macromol. 2007;41(3):266-73.

18. Blackburn S, Lee GR. The reaction of wool keratin with alkali. Biochim Biophys Acta. 1956;19:505-12.

19. Vasileva-Tonkova E, Gousterova A, Neshev G. Ecologically safe method for improved feather wastes biodegradation. Int Biodeterior Biodegradation. 2009;63(8):1008-101.

20. Berechet MD, Niculescu MD, Gaidau C, Ignat M, Epure DG. Alkalineenzymatic hydrolysis of wool waste for different applications. Rev Chim. 2018;69(7):1649-54.

21. Mokrejš $P$, Krejčí $O$, Svoboda P. Producing keratin hydrolysates from sheep wool. Orient J Chem. 2011;27(4):1303-9.

22. Chen J, Ding S, Ji Y, Ding J, Yang X, Zou M, Li Z. Microwave-enhanced hydrolysis of poultry feather to produce amino acid. Chem Eng Process Process Intensif. 2015:87:104-9.

23. Idris A, Vijayaraghavan R, Rana UA, Patti AF, MacFarlane DR. Dissolution and regeneration of wool keratin in ionic liquids. Green Chem. 2014 16(5):2857-64

24. Xie H, Li S, Zhang S. lonic liquids as novel solvents for the dissolution and blending of wool keratin fibers. Green Chem. 2005;7(8):606-8.

25. Rajabinejad H, Zoccola M, Patrucco A, Montarsolo A, Rovero G, Tonin C. Physicochemical properties of keratin extracted from wool by various methods. Text Res J. 2017;88(21):2415-24.

26. Ghosh A, Clerens S, Deb-Choudhury S, Dyer JM. Thermal effects of ionic liquid dissolution on the structures and properties of regenerated wool keratin. Polym Degrad Stab. 2014;108:108-15.

27. Wang K, Li R, Ma JH, Jian YK, Che JN. Extracting keratin from wool by using I-cysteine. Green Chem. 2016;18(2):476-81.

28. Cassoni AC, Freixo R, Pintado AIE, Amorim M, Pereira CD, Madureira AR, Pintado MME. Novel eco-friendly method to extract keratin from hair. ACS Sustain Chem Eng. 2018;6(9):12268-74.

29. Tachibana A, Nishikawa Y, Nishino M, Kaneko S, Tanabe T, Yamauchi K Modified keratin sponge: binding of bone morphogenetic protein-2 and osteoblast differentiation. J Biosci Bioeng. 2006;102(5):425-9.

30. Li JS, Li Y, Liu X, Zhang J, Zhang Y. Strategy to introduce an hydroxyapatitekeratin nanocomposite into a fibrous membrane for bone tissue engineering. J Mater Chem B. 2013;1(4):432-7.

31. Lin YC, Ramadan M, Van Dyke M, Kokai LE, Philips BJ, Rubin JP, Marra KG. Keratin gel filler for peripheral nerve repair in a rodent sciatic nerve injury model. Plast Reconstr Surg. 2012;129(1):67-78.

32. Apel PJ, Garrett JP, Sierpinski P, Ma J, Atala A, Smith TL, Van Dyke ME. Peripheral nerve regeneration using a keratin-based scaffold: long-term functional and histological outcomes in a mouse model. The Journal of Hand Surgery. 2008;33(9):1541-7.

33. Nakata R, Tachibana A, Tanabe T. Preparation of keratin hydrogel/ hydroxyapatite composite and its evaluation as a controlled drug release carrier. Mater Sci Eng C. 2014;41:59-64.

34. Ham TR, Lee RT, Han S, Haque S, Vodovotz Y, Gu J, Saul JM. Tunable keratin hydrogels for controlled Erosion and growth factor delivery. Biomacromolecules. 2015;17(1):225-36.

35. Aboushwareb T, Eberli D, Ward C, Broda C, Holcomb J, Atala A, Van Dyke M. A keratin biomaterial gel hemostat derived from human hair: evaluation in a rabbit model of lethal liver injury. J Biomed Mater Res B Appl Biomater. 2008;90(1):45-54.

36. Guo J, Pan S, Yin X, He YF, Li T, Wang RM. pH-sensitive keratin-based polymer hydrogel and its controllable drug-release behavior. J Appl Polym Sci. 2014:132(9):41572

37. Yin XC, Li FY, He YF, Wang Y, Wang RM. Study on effective extraction of chicken feather keratins and their films for controlling drug release. Biomaterials Science. 2013;1(5):528-36.

38. Li T, Yin X, Zhai W, He YF, Wang RM. Enzymatic digestion of keratin for preparing a pH-sensitive biopolymer hydrogel. Aust J Chem. 2016;69(2): 191-7.

39. Tachibana A, Furuta Y, Takeshima H, Tanabe T, Yamauchi K. Fabrication of wool keratin sponge scaffolds for long-term cell cultivation. J Biotechnol. 2002;93(2):165-70.

40. Srinivasan B, Kumar R, Shanmugam K, Sivagnam UT, Reddy NP, Sehgal PK. Porous keratin scaffold-promising biomaterial for tissue engineering and drug delivery. J Biomed Mater Res B Appl Biomater. 2010;92(1):5-12.

41. Ozaki Y, Takagi $Y$, Mori $H$, Hara M. Porous hydrogel of wool keratin prepared by a novel method: an extraction with guanidine/2-mercaptoethanol solution followed by a dialysis. Mater Sci Eng C. 2014;42:146-54.

42. Aluigi A, Sotgiu G, Torreggiani A, Guerrini A, Orlandi VT, Corticelli F, Varchi G. Methylene blue doped films of wool keratin with antimicrobial photodynamic activity. ACS Appl Mater Interfaces. 2015;7(31):17416-24.

43. Tran CD, Mututuvari TM. Cellulose, chitosan, and keratin composite materials. Langmuir. 2015;31(4):1516-26.

44. Tran CD, Mututuvari TM. Cellulose, chitosan and keratin composite materials: facile and recyclable synthesis, conformation and properties. ACS Sustain Chem Eng. 2016;4(3):1850-61.

45. Tran CD, Prosenc F, Franko M, Benzi G. One-pot synthesis of biocompatible silver nanoparticle composites from cellulose and keratin: characterization and antimicrobial activity. ACS Appl Mater Interfaces. 2016;8(50):34791-801.

46. Aluigi A, Ballestri M, Guerrini A, Sotgiu G, Ferroni C, Corticelli F, Varchi G. Organic solvent-free preparation of keratin nanoparticles as doxorubicin carriers for antitumour activity. Mater Sci Eng C. 2018;90:476-84.

47. Aluigi A, Rombaldoni F, Tonetti C, Jannoke L. Study of methylene blue adsorption on keratin nanofibrous membranes. J Hazard Mater. 2014;268: 156-65.

48. Aluigi A, Tonetti C, Vineis C, Tonin C, Mazzuchetti G. Adsorption of copper (II) ions by keratin/PA6 blend nanofibres. Eur Polym J. 2011;47(9):1756-64.

49. Aluigi A, Corbellini A, Rombaldoni F, Mazzuchetti G. Wool-derived keratin nanofiber membranes for dynamic adsorption of heavy-metal ions from aqueous solutions. Text Res J. 2012;83(15):1574-86.

50. Sekimoto Y, Okiharu T, Nakajima H, Fujii T, Shirai K, Moriwaki H. Removal of $\mathrm{Pb}(\mathrm{II})$ from water using keratin colloidal solution obtained from wool. Environ Sci Pollut Res. 2013;20(9):6531-8.

51. Aluigi A, Tonetti C, Vineis C, Varesano A, Tonin C, Casasola R. Study on the adsorption of chromium (VI) by hydrolyzed keratin/polyamide 6 blend Nanofibres. J Nanosci Nanotechnol. 2012;12(9):7250-9.

52. Song $\mathrm{K}, \mathrm{Xu} \mathrm{H}, \mathrm{Xu} \mathrm{L}$, Xie K, Yang Y. Cellulose nanocrystal-reinforced keratin bioadsorbent for effective removal of dyes from aqueous solution. Bioresour Technol. 2017:232:254-62.

53. Liu J, Zhang FF, Li YC, Du Y. Method for preparing magnetic nano-bovine hair keratin sponge. CN. 2018;201810263155:2.

54. Liu J., Zhang F.F., Li Y.C., \& Liu Z.C. (2018). Preparation method of cow hair protein sponge adsorption material for tanning dyeing waste liquid. CN201810263355.8.

55. Sastry TP. Solubilized keratins as a novel filler in the retanning of upper leathers. Leather Science. 1986;33:345-59.

56. Sehgal PK, Sastry TP, Kumar M. Studies on solubilised keratins from poultry feathers. Leather Science. 1986;33:333. 
57. Liang YX, Wen HT, Yang YQ, Niu Z, Sun HY, Dan WH. Study on preparation of protein filler by dicyandiamide modified keratin. Leather and Chemicals. 2017;34(4):1-8.

58. $Y u$ Y, Zeng $W$, Wang $Y$, Shi B. Inhibitory effect of protein filling agent from bovine hair on the oxidation of $\mathrm{Cr}$ (III). J Am Leather Chem Assoc. 2015;110: 385-91.

59. Masilamani D, Srinivasan V, Ramachandran RK, Gopinath A, Madhan B, Saravanan P. Sustainable packaging materials from tannery trimming solid waste: A new paradigm in wealth from waste approaches. J Clean Prod. 2017; 164:885-91.

60. Yang H, Jiang Y, Ding S, Wang H, Liu J, Bi L, Shu Z. Preparation of collagen burn-healing membranes. J Chem Pharm Res. 2014;6(5):1035-9.

61. Fan X, Li N, Tang K, Albu MG. Nano-TiO 2 hydrosol/collagen-chitosan composite scaffold for wound repairing. In: 5 th international conference on advanced materials and systems; 2014. p. 207-12.

62. Murali R, Anumary A, Ashokkumar M, Thanikaivelan P, Chandrasekaran B. Hybrid biodegradable films from collagenous wastes and natura polymers for biomedical applications. Waste and Biomass Valorization. 2011;2(3):323-35.

63. Mendrycka M, Kowalska M, Myjak W. Assessment of the properties of emulsions containing different amounts of collagen derived from calf skins. Materiale Plastice. 2016;53(1):113-8.

64. Thanikaivelan P, Narayanan NT, Pradhan BK, Ajayan PM. Collagen based magnetic nanocomposites for oil removal applications. Sci Rep. 2012;2:230

65. Ashokkumar M, Narayanan NT, Reddy ALM, Gupta BK, Chandrasekaran B, Talapatra S, Thanikaivelan P. Transforming collagen wastes into doped nanocarbons for sustainable energy applications. Green Chem. 2012;14(6): 1689-95.

66. Sundar VJ, Gnanamani A, Muralidharan C, Chandrababu NK, Mandal AB. Recovery and utilization of proteinous wastes of leather making: a review. Rev Environ Sci Biotechnol. 2011;10(2):151-63.

67. Devaraj K, Aathika S, Mani Y, Thanarasu A, Periyasamy K, Periyaraman P, Subramanian S. Experimental investigation on cleaner process of enhanced fat-oil extraction from alkaline leather fleshing waste. J Clean Prod. 2018;175:1-7.

68. Vasudevan N, Ravindran AD. Biotechnological process for the treatment of fleshing from tannery industries for methane generation. Curr Sci. 2007; 93(11):1492-4.

69. Kolomazník K, Uhliřová M, Fürst T. Possibility of using tannery waste for biodiesel production. J Am Leather Chem Assoc. 2009;104(5):177-82.

70. Colak SM, Zengin G, Özgünay H, Sari Ö, Sarikahya H, Yüceer L. Utilization of leather industry prefleshings in biodiesel production. J Am Leather Chem Assoc. 2005:100(4):137-41.

71. Ma, J.Z., Ma, D., Bin, Lv, B., \&, Yan, M.J. (2011). Preparation of emulsifier for ethanol-diesel fuel from tannery waste oil. Petroleum Processing \& Petrochemicals, 42(10), 73-77.

72. Salma Aathika A. R, Kubendran, D., Yuvarani, M., Thiruselvi, D., Amudha, T., Karthik, P., \& Sivanesan, S. (2018). Enhanced biohydrogen production from leather fleshing waste co-digested with tannery treatment plant sludge using anaerobic hydrogenic batch reactor. Energy Sources, Part A: Recovery, Utilization, and Environmental Effects, 40(5), 586-593.

73. Nasr A. Reusing limed fleshing wastes as A Fatliquor in leather processing. Egypt J Chem. 2017;60(5):919-28.

74. Yang JE, Shan ZH, Zhang YW, Chen LW. Stabilization and cyclic utilization of chrome leather shavings. Environ Sci Pollut Res. 2019:26:4680-9.

75. Liu YJ, Hu GL. Optimization of scouring agent for electrostatic flocking of leather fluff. Advanced Textile Technology. 2017;25(2):17-20.

76. Ding ZW, Chen JG, Xu XL, Chen ZP. Regenerated leather fiber leather and preparation method thereof. CN. 2011;201110087248:2.

77. Ding C, Zhang M, Dai L, Qi Y, Shi R, Yang J. Fabrication and characterization of regenerated leather using chrome shavings as raw materials. J Am Leather Chem Assoc. 2017;112(5):145-52.

78. Konikkara N, Kennedy LJ, Vijaya JJ. Preparation and characterization of hierarchical porous carbons derived from solid leather waste for supercapacitor applications. J Hazard Mater. 2016;318:173-85.

79. Konikkara N, Kennedy $L$, Aruldoss U, Vijaya JJ. Electrical conductivity studies of Nanoporous carbon derived from leather waste: effect of pressure, temperature and porosity. J Nanosci Nanotechnol. 2016;16(8): 8829-38.

80. Lardizabal-Guitierrez D, González-Quijano D, Bartolo-Pérez P, EscobarMorales B, Rodríguez-Varela FJ, Alonso-Lemus IL. Communication—synthesis of self-doped metal-free Electrocatalysts from waste leather with high ORR activity. J Electrochem Soc. 2015;163(2):H15-7.

81. Oliveira DQL, Gonçalves M, Oliveira LCA, Guilherme LRG. Removal of as( $(V)$ and $\mathrm{Cr}(\mathrm{VI})$ from aqueous solutions using solid waste from leather industry. J Hazard Mater. 2008;151(1):280-4.

82. Chabaane L, Tahiri S, Albizane A, Krati ME, Cervera ML, de la Guardia M. Immobilization of vegetable tannins on tannery chrome shavings and their use for the removal of hexavalent chromium from contaminated water. Chem Eng J. 2011;174(1):310-7.

83. Kantarli IC, Yanik J. Activated carbon from leather shaving wastes and its application in removal of toxic materials. J Hazard Mater. 2010; 179(1-3):348-56.

84. $\mathrm{Xu} \mathrm{W}$, Hao L. The feasibility of chrome shaving to remove $\mathrm{Cr}$ (III) from aqueous solutions. 2011 International Symposium on Water Resource and Environmental Protection. 2011. https://doi.org/10.1109/iswrep.2011.5893349.

85. Yan T, Luo X, Zou Z, Lin X, He Y. Adsorption of uranium (VI) from a simulated saline solution by alkali-activated leather waste. Ind Eng Chem Res. 2017:56(12):3251-8.

86. Yan T, Luo X, Lin X, Yang J. Preparation, characterization and adsorption properties for lead (II) of alkali-activated porous leather particles. Colloids Surf A Physicochem Eng Asp. 2017:512:7-16.

87. Sreeram KJ, Saravanabhavan S, Rao JR, Nair BU. Use of chromium-collagen wastes for the removal of tannins from wastewaters. Ind Eng Chem Res. 2004;43(17):5310-7.

88. Oliveira LCA, Coura CVZ, Guimarães IR, Gonçalves M. Removal of organic dyes using $\mathrm{Cr}$-containing activated carbon prepared from leather waste. J Hazard Mater. 2011;192(3):1094-9.

89. Gomes CS, Piccin JS, Gutterres M. Optimizing adsorption parameters in tannery-dye-containing effluent treatment with leather shaving waste. Process Saf Environ Prot. 2016:99:98-106.

90. Piccin JS, Gomes CS, Mella B, Gutterres M. Color removal from real leather dyeing effluent using tannery waste as an adsorbent. Journal of Environmental Chemical Engineering. 2016;4(1):1061-7.

91. Dettmer A, Nunes KGP, Gutterres M, Marcílio NR. Production of basic chromium sulfate by using recovered chromium from ashes of thermally treated leather. J Hazard Mater. 2010;176(1-3):710-4.

92. Wionczyk, B., Apostoluk, W., Charewicz, W.A., \& Adamski, Z. (2011) Recovery of chromium (III) from wastes of uncolored chromium leathers. Part I Kinetic studies on alkaline hydrolytic decomposition of the wastes Separation and Purification Technology, 81(2), 223-236.

93. Pati A, Chaudhary R, Subramani S. Biochemical method for extraction and resue of protein and chromium from chrome leather shavings: A waste to wealth approach. J Am Leather Chem Assoc. 2013;108(10):365-72.

94. Pillai $P$, Archana G. A novel process for biodegradation and effective utilization of chrome shavings, a solid waste generated in tanneries, using chromium resistant Bacillus subtilis P13. Process Biochem. 2012; 47(12):2116-22.

95. Erdem M. Chromium recovery from chrome shaving generated in tanning process. J Hazard Mater. 2006:129(1-3):143-6.

96. Rao JR, Thanikaivelan P, Sreeram KJ, Nair BU. Green route for the utilization of chrome shavings (chromium-containing solid waste) in tanning industry. Environmental science \& technology. 2002;36(6):1372-6.

97. Sharaf SAA, Gasmeleed GA, Musa AE. Reduction of hexavalent chromium from chrome shavings. International Journal of Advance Industrial Engineering. 2013:1:24-7.

98. Lazău Rl, Păcurariu C, Becherescu D, lanoş R. Ceramic pigments with chromium content from leather wastes. J Eur Ceram Soc. 2007;27(2-3): 1899-903.

99. Cunha GD, Peixoto JA, de Souza DR, Romao LPC, Macedo ZS. Recycling of chromium wastes from the tanning industry to produce ceramic nanopigments. Green Chem. 2016;18(19):5342-56.

100. Ferreira MJ, Almeida MF, Pinho SC, Santos IC. Finished leather waste chromium acid extraction and anaerobic biodegradation of the products. Waste Manag. 2010;30(6):1091-100.

101. Tahiri S, Bouhria M, Albizane A, Messaoudi A, Azzi M, Alami Younssi S, Mabrour J. Extraction of proteins from chrome shavings with sodium hydroxide and reuse of chromium in the tanning process. J Am Leather Chem Assoc. 2004:99(1):16-25.

102. Brown EM, Taylor MM, Marmer WN. Production and potential uses of co-products from solid tannery waste. J Am Leather Chem Assoc. 1996; 91(10):270-6. 
103. Holloway DF. Process for recovery and separation of nutritious protein hydrolysate and chromium from chrome leather scrap. 1978:US4100154.

104. Su, D.Q., Hu, Y., Wang, K.Y., Zhang, K.C., Li, H., \& Chen, X.W. (2008). Extraction of collagen hydrolysate from chrome shavings with sodium hydroxide. Leather Science \& Engineering, 18(5), 8-11.

105. Ding, W., Liao, X. P, Zhang, W.H., \& Shi, B. (2015). Dechroming of chromiumcontaining leather waste with low hydrolysis degree of collagen. Journal of the Society of Leather Technologies and Chemists, 99, 129-133.

106. Zhou W, Dan WH. Extraction of collagen hydrolysate from chrome shavings with enzymes. China Leather. 2012;41(13):25-9.

107. Yuan WH, Zhang LP, Li HW, Wu SS. Dechroming process of chrome shavings by oxidation. Leather \& Chemicals. 2011;28(2):6-9.

108. Chen C, Dan WH, Ceng R, Qu JJ, Lin H. Study on oxidation dechrome for shaving containing chrome. Leather Science \& Engineering. 2006; 16(2):22-5.

109. Sethuraman C, Srinivas K, Sekaran G. Pyrolysis coupled pulse oxygen incineration for disposal of hazardous chromium impregnated fine particulate solid waste generated from leather industry. Journal of Environmental Chemical Engineering. 2014;2(1):516-24.

110. Bañón E, Marcilla A, García AN, Martínez P, León M. Kinetic model of the thermal pyrolysis of chrome tanned leather treated with $\mathrm{NaOH}$ under different conditions using thermogravimetric analysis. Waste Manag. 2016; 48:285-99.

111. Wells HC, Sizeland KH, Edmonds RL, Aitkenhead W, Kappen P, Glover C, Haverkamp RG. Stabilizing chromium from leather waste in biochar. ACS Sustain Chem Eng. 2014;2(7):1864-70.

112. Taylor MM, Marmer WN, Brown EM. Characterization of biopolymers prepared from gelatin and sodium caseinate for potential use in leather processing. J Am Leather Chem Assoc. 2005;100(4):149-59.

113. Chen W, Cooke PH, DiMaio GL, Taylor MM, Brown EM. Modified collagen hydrolysate, potential for use as a filler for leather. J Am Leather Chem Assoc. 2001:96(7):262-7.

114. Cao J, LV YH, Chang GY, Tang KY. Study on the glutaraldehyde modification of collagen obtained from chrome shavings. China Leather. 2005;34(5):21-6.

115. Catalina M, Attenburrow GE, Cot J, Covington AD, Antunes APM. Application of gelatin extracted from chrome shavings for the glazed finishing of leather. Journal of American Leather Chemists Association. 2010; 105(5):138-74

116. Li W, Qin SF, Zhang XJ, Tang KY, Wang QJ. The modification of polyurethane finishing agent with collagen. Polymer Materials Science \& Engineering. 2008;24(5):151-4.

117. Figueiro S, Goes J, Moreira R, Sombra A. On the physico-chemical and dielectric properties of glutaraldehyde crosslinked galactomannan-collagen films. Carbohydr Polym. 2004;56(3):313-20.

118. Zhang GH, Liu LJ, Wang F. Study on preparing gelatin graft copolymer emulsion as sizing agent. China Adhesives. 2011;20(4):26-30.

119. Kašpárková V, Kolomazník K, Burketová L, Šašek V, Šimek L. Characterization of low-molecular weight collagen hydrolysates prepared by combination of enzymatic and acid hydrolysis. Journal of American Leather Chemists Association. 2009;104(2):46-51.

120. Katsifas EA, Giannoutsou E, Lambraki M, Barla M, Karagouni AD. Chromium recycling of tannery waste through microbial fermentation. J Ind Microbiol Biotechnol. 2004;31(2):57-62.

121. Sirbu C, Cioroianu T, Dumitru M, Dorneanu A, Negrila M, Mihalache D, Angelescu L. New structures of biofertilizers with chelate proteinic substances with role of biostimulator and protection for sustainable agriculture. Seria Agronomie. 2008;51(2):189-94.

122. Gil CSB, Gil VSB, Carvalho SM, Silva GR, Magalhães J, Oréfice RL, Oliveira LCA. Recycled collagen films as biomaterials for controlled drug delivery. New J Chem. 2016;40(10):8502-10.

123. Yang $M$, Zhen $W$, Chen $H$, Shan Z. Biomimetic Design of Oxidized Bacterial Cellulose-gelatin-hydroxyapatite Nanocomposites. Journal of Bionic Engineering. 2016;13(4):631-40.

124. Dang X, Li Y, Yang M. Biodegradable waterborne polyurethane grafted with gelatin hydrolysate via solvent-free copolymerization for potentia porous scaffold material. J Mech Behav Biomed Mater. 2019;92:79-89.

125. Shakilanishi S, Chandra Babu NK, Shanthi C. Exploration of chrome shaving hydrolysate as substrate for production of dehairing protease by Bacillus cereus VITSN04 for use in cleaner leather production. J Clean Prod. 2017; 149:797-804.
126. Ramalingam S, Sreeram KJ, Rao JR, Nair BU. Hybrid composites: amalgamation of proteins with polymeric phenols as a multifunctional material for leather processing. RSC Adv. 2015;5(42):33221-32.

127. Tang K, Zheng X, Li W, Shelly DC, Casadonte DJ Jr. Modification of polyurethane finishing agent using collagen hydrolysate from chrome shavings. J Am Leather Chem Assoc. 2010;105(1):25-31.

128. Wang XC, Hao XL, Qiang TT. Preparation and sizing performance of the modified collagen surface sizing agent. Appl Mech Mater. 2012;271-272: 367-71.

129. Wang, Q., Zhang, S.F., Dou, W.W., D., Wang, X.C., W., \& Qiang, T.T. (2015). Application of hydrolyzed collagen in paper industry. China Leather, 44(5), 25-28.

130. Ocak B. Film-forming ability of collagen hydrolysate extracted from leather solid wastes with chitosan. Environ Sci Pollut Res. 2017;25(5):4643-55.

131. Pati A, Chaudhary R. Soybean plant growth study conducted using purified protein hydrolysate-based fertilizer made from chrome-tanned leather waste. Environ Sci Pollut Res. 2015;22(24):20316-2032.

132. Chaudhary R, Pati A. Poultry feed based on protein hydrolysate derived from chrome-tanned leather solid waste: creating value from waste. Environ Sci Pollut Res. 2016;23(8):8120-4.

133. Nogueira, F.G., do Prado, N.T., Oliveira, L.C., Bastos, A.R., Lopes, J.H., \& de Carvalho, J.G. (2010). Incorporation of mineral phosphorus and potassium on leather waste (collagen): A new NcollagenPK-fertilizer with slow liberation. J Hazard Mater, 176(1-3), 374-380.

134. Dang X, Yuan H, Shan Z. An eco-friendly material based on graft copolymer of gelatin extracted from leather solid waste for potential application in chemical sand-fixation. J Clean Prod. 2018;188:416-24.

135. Brey Gil CS, Patricio PS, Oliveira LC, Oréfice RL. Improved self-healing properties of collagen using polyurethane microcapsules containing reactive diisocyanate. Polym Int. 2016;65(6):721-7.

136. Karak T, Kutu FR, Paul RK, Bora K, Das DK, Khare P, Boruah RK. Cocomposting of cow dung, municipal solid waste, roadside pond sediment and tannery sludge: role of human hair. Int J Environ Sci Technol. 2016; 14(3):577-94.

137. Kameswari KSB, Kalyanaraman C, Subramanian P, Thanasekaran K Enhancement of biogas generation by addition of lipase in the co-digestion of tannery solid wastes. Clean - Soil, Air, Water. 2011;39(8):781-6.

138. Chen, J., Li, X.X., Jia, J.Z. (2013). Pretreatment method for anaerobic digestion of tannery sludge. CN 201310111955.X.

139. Juel MAl, Mizan A, Ahmed T. Sustainable use of tannery sludge in brick manufacturing in Bangladesh. Waste Manag. 2017;60:259-69.

140. Liu J, Li YC, Du Y, Zheng LW, Chen YF. Performances of Ceramisite made by tannery sludge. China Leather. 2011;40(9):1-5.

141. Li G, Bai L, Chang W, Jia Q, Li Y, Zhang L. Effect of sodium salt catalyst on oil derived from pyrolysis of tannery sludge. Acta Energiae Solaris Sinica. 2013:34(3):407-12

142. Geethakarthi A, Phanikumar BR. Characterization of tannery sludge activated carbon and its utilization in the removal of azo reactive dye. Environ Sci Pollut Res. 2011;19(3):656-65

143. Teklay A, Gebeyehu G, Getachew T, Yaynshet T, Sastry TP. Preparation of value added composite boards using finished leather waste and plant fibers - a waste utilization effort in Ethiopia. Clean Techn Environ Policy. 2017;19(5):1285-96.

144. Senthil R, Inbasekaran S, Gobi N, Das BN, Sastry TP. Utilisation of finished leather wastes for the production of blended fabrics. Clean Techn Environ Policy. 2014;17(6):1535-46.

145. Senthil R, Hemalatha T, Kumar BS, Uma TS, Das BN, Sastry TP. Recycling of finished leather wastes: a novel approach. Clean Techn Environ Policy. 2014; 17(1):187-97.

\section{Publisher's Note}

Springer Nature remains neutral with regard to jurisdictional claims in published maps and institutional affiliations. 